Atmos. Chem. Phys., 18, 10849-10867, 2018

https://doi.org/10.5194/acp-18-10849-2018

(C) Author(s) 2018. This work is distributed under

the Creative Commons Attribution 4.0 License.

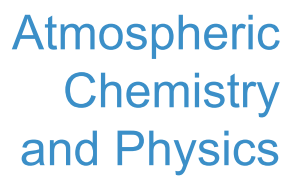

(c) (P)

\title{
Light absorption by polar and non-polar aerosol compounds from laboratory biomass combustion
}

\author{
Deep Sengupta $^{1}$, Vera Samburova ${ }^{1}$, Chiranjivi Bhattarai ${ }^{1}$, Elena Kirillova ${ }^{2}$, Lynn Mazzoleni ${ }^{2}$, \\ Michealene Iaukea-Lum ${ }^{1}$, Adam Watts ${ }^{1}$, Hans Moosmüller ${ }^{1}$, and Andrey Khlystov ${ }^{1}$ \\ ${ }^{1}$ Desert Research Institute, 2215 Raggio Parkway, Reno, NV 89512, USA \\ ${ }^{2}$ Michigan Technological University, 1400 Townsend Drive, Houghton, MI 49931, USA
}

Correspondence: Vera Samburova (vera.samburova@dri.edu)

Received: 11 February 2018 - Discussion started: 15 March 2018

Revised: 28 June 2018 - Accepted: 3 July 2018 - Published: 3 August 2018

\begin{abstract}
Fresh and atmospherically aged biomass-burning (BB) aerosol mass is mostly comprised of strongly lightabsorbing black carbon (BC) and of organic carbon (OC) with its light-absorbing fraction - brown carbon $(\mathrm{BrC})$. There is a lack of data on the physical and chemical properties of atmospheric BB aerosols, leading to high uncertainties in estimates of the BB impact on air quality and climate, especially for $\mathrm{BrC}$. The polarity of chemical compounds influences their fate in the atmosphere including wet/dry deposition and chemical and physical processing. So far, most of the attention has been given to the water-soluble (polar) fraction of $\mathrm{BrC}$, while the non-polar $\mathrm{BrC}$ fraction has been largely ignored. In the present study, the light absorption properties of polar and non-polar fractions of fresh and aged BB emissions were examined to estimate the contribution of differentpolarity organic compounds to the light absorption properties of BB aerosols.

In our experiments, four globally and regionally important fuels were burned under flaming and smoldering conditions in the Desert Research Institute (DRI) combustion chamber. To mimic atmospheric oxidation processes (5-7 days), BB emissions were aged using an oxidation flow reactor (OFR). Fresh and OFR-aged BB aerosols were collected on filters and extracted with water and hexane to study absorption properties of polar and non-polar organic species. Results of spectrophotometric measurements (absorption weighted by the solar spectrum and normalized to mass of fuel consumed) over the 190 to $900 \mathrm{~nm}$ wavelength range showed that the non-polar (hexane-soluble) fraction is $2-3$ times more absorbing than the polar (water-soluble) fraction. However, for emissions from fuels that undergo flaming combustion,
\end{abstract}

an increased absorbance was observed for the water extracts of oxidized/aged emissions while the absorption of the hexane extracts was lower for the aged emissions for the same type of fuels. Absorption Ångström exponent (AAE) values, computed based on absorbance values from spectrophotometer measurements, were changed with aging and the nature of this change was fuel dependent. The light absorption by humic-like substances (HULIS) was found to be higher in fuels characteristic of the southwestern USA. The absorption of the HULIS fraction was lower for OFR-aged BB emissions. Comparison of the light absorption properties of different-polarity extracts (water, hexane, HULIS) provides insight into the chemical nature of $\mathrm{BB} \mathrm{BrC}$ and its transformation during oxidation processes.

\section{Introduction}

Biomass burning (BB), including wildfires and controlled burns, can contribute significantly to the atmospheric aerosol loading (Park et al., 2007). BB emissions alter regional air quality (Liu et al., 2009), cause radiative forcing and contribute to climate change (Jacobson, 2004), reduce visibility (Lee et al., 2016), and cause adverse health effects (Arbex et al., 2007; Regalado et al., 2006). BB is a major source of greenhouse gases (e.g., $\mathrm{CO}_{2}$ ), volatile organic compounds (VOCs), $\mathrm{NO}_{x} \mathrm{CO}$, and carbonaceous aerosols in the atmosphere (Finlayson-Pitts and Pitts, 1999). In addition to greenhouse gases, carbonaceous particles can perturb the radiation budget of the Earth's atmosphere (Hobbs et al., 1997; Pod- 
gorny et al., 2003) due to their light scattering and absorbing properties (Corr et al., 2012; C. Liu et al., 2016).

Until recently, black carbon (BC) was considered to be the only light-absorbing compound in atmospheric carbonaceous aerosols (Ramanathan et al., 2001). Based on this premise, climate model simulations used known BC mass concentrations to compute aerosol absorption optical depths, which were compared with surface and satellite-based observations (Holben et al., 1998; Torres et al., 2007). Discrepancies between simulated radiative forcing estimates with known BC mass concentrations and observed absorption values were high in regions dominated by BB aerosols (Koch et al., 2009). Both laboratory-based studies (Shiraiwa et al., 2010) and field campaigns (Cappa et al., 2012; China et al., 2013; Gyawali et al., 2017; Lack and Cappa, 2010) offer compelling evidence in favor of the ubiquitous existence of nonBC light-absorbing compounds in carbonaceous aerosols. The light-absorbing organic compounds are known as brown carbon $(\mathrm{BrC})$, mostly due to their brownish color (Formenti, 2003). They are abundant in BB aerosols and strongly absorb light in the UV and near-UV visible region of the spectrum (Bond and Bergstrom, 2006; Kirchstetter et al., 2004; Moosmüller et al., 2009).

$\mathrm{BrC}$ chemical composition and light absorption efficiency vary depending on the fuels, burning conditions (Akagi et al., 2011; Jaffe and Wigder, 2012), and degree of atmospheric oxidation (Andreae and Gelencsér, 2006; Hoffer et al., 2006). In order to understand the global impact of BB organic aerosols (BBOAs) on atmospheric processes and climate, comprehensive characterization of their $\mathrm{BrC}$ fraction generated during combustion of relevant fuels from different geographical locations is needed. BB processes and the subsequent atmospheric aging (Andreae, 1997) can produce a wide range of compounds including water-soluble HULIS (Graber and Rudich, 2006) and polycyclic aromatic hydrocarbons (PAHs; Samburova et al., 2016). However, very little is known about light absorption properties of other BB organic compounds.

In the present study, we investigated BB emissions from several globally and regionally important fuels and characterized light absorption by $\mathrm{BrC}$ in BBOA extracts of different polarity. While the water-soluble fraction of $\mathrm{BB}$ aerosols has attracted much attention (Kiss et al., 2002; Mayol-Bracero et al., 2002), only a few studies (Chen and Bond, 2010) have reported light absorption properties of non-polar BBOAs extracted with lower-polarity solvents. Characterization of light-absorbing compounds extracted with different-polarity solvents can greatly improve our understanding of the $\mathrm{BB}$ aerosol chemistry, wet and dry deposition of $\mathrm{BB}$ aerosols, and effects of $\mathrm{BB}$ aerosols, in particular of their $\mathrm{BrC}$ fraction, on regional and global radiative forcing. Spectrophotometric characterization of different-polarity BB extracts was performed to analyze their light absorption properties in both fresh and oxidized states. These results were supplemented with ultrahigh-resolution Orbitrap Elite mass spectrometry observations of the high molecular weight fraction of the water-soluble aerosol.

\section{Experiments}

\subsection{Fuel description}

Several globally and regionally important BB fuels were selected for the present study. They can be divided into two categories: (1) fuels that burn mostly with smoldering combustion and (2) fuels that burn mostly with flaming combustion.

Smoldering combustion: Florida peat from southeastern USA, used for our study, is a semi-tropical fuel and consists of organic mucky peat and swamp soils (Watts, 2013; Watts and Kobziar, 2013). Wetlands in the southeastern USA are currently under tremendous stress due to urbanization and increasing demand for water resources. The resulting desiccated wetlands are considered to be fire prone zones and can cause large carbon emissions during wildland fires.

Eurasian peatlands host a large part of the global carbon pool (Yu, 2012) and are also highly vulnerable to wildfires due to climatic warming, permafrost degradation, and prolonged fire seasons (Brown et al., 2015; Turetsky et al., 2015). For this study peat samples were collected from the Pskov region of Russia. The indigenous species that are responsible for peat formation in this region are Sphagnum and cotton grass (Eriophorum spp.).

Flaming combustion: for flaming combustion fuel, we collected vegetation from the Fishlake National Forest, UT, USA where the Joint Fire Science Program (JFSP) of the US land management agencies is planning to conduct large prescribed burns as part of the Fire and Smoke Model Evaluation Experiment (FASMEE). Dominant species are subalpine fir (Abies lasiocarpa) and quaking aspen (Populus tremuloides); minor species include Douglas fir (Pseudotsuga menziesii), limber pine (Pinus flexilis), and common juniper (Juniperus communis). Another flaming combustiontype fuel was collected in the immediate vicinity of a local, Reno, NV, fire event that occurred in June 2016 (Hawken Fire) on the lower eastern slope of the Sierra Nevada's Carson Range. This fuel is characteristic of vegetation of the southwestern USA and is dominated by grasses, shrubs, shadscale (Atriplex confertifolia), sagebrush (Artemisia arbuscula), and antelope brush (Purshia tridentata).

\subsection{Reagents and materials}

Polycyclic aromatic hydrocarbon standards were acquired from Sigma-Aldrich (St. Louis, MO, USA), AccuStandard (New Haven, CT, USA), and Cambridge Isotope Laboratories, Inc. (Andover, MA, USA). High-performance liquid chromatography (HPLC) grade methanol and hexane were obtained from Fisher Scientific (Fair Lawn, NJ, USA). Nanopure water was generated with a Barnstead Nanopure 
instrument (Thermo Scientific, Dubuque, IA, USA). Solidphase extraction was performed using Waters Oasis HLB cartridges (Waters, Milford, MA, USA). Three different kinds of filters were used for sampling and further chemical analyses: (1) pre-fired $\left(900^{\circ} \mathrm{C}\right.$ for $\left.4 \mathrm{~h}\right) 47 \mathrm{~mm}$ diameter quartz-fiber filters (2500 Pallflex QAT-UP, Pall Life Sciences, Ann Arbor, MI, USA) for thermal-optical elemental carbon/organic carbon (EC/OC) analysis, (2) Teflon filters (2500 Pallflex QATUP, Pall Life Science, Ann Arbor, MI, USA) for gravimetric particulate matter (PM) mass analysis, and (3) Teflonimpregnated glass fiber (TIGF) $47 \mathrm{~mm}$ diameter filters (Fiber FilmT60A20, Pall Life Sciences, Ann Arbor, MI, USA) for organic analysis.

\subsection{Biomass-burning experiments}

BB experiments were conducted using the Desert Research Institute (DRI) BB facility for combustion of the selected fuels under controlled conditions. A close replicate of this facility was described previously (Tian et al., 2015) and a detailed discussion of the experimental set up can be found elsewhere (Bhattarai et al., 2018). Fuels were placed on a burn platform that consists of a ceramic disk $(d=45.7 \mathrm{~cm})$ on top of a balance (Veritas L Series Precision Balance, Hogentogler \& Co. Inc., Columbia, MD, USA; $0.01 \mathrm{~g}$ precision). A propane burner (Worthington Cylinder Corporation Columbus, $\mathrm{OH}$, USA) was used to initiate the burns. During each burn, the mass on the burn platform was recorded every $2 \mathrm{~s}$. A burn was considered complete when no significant change in fuel mass was observed for 2 min or longer.

Laboratory-generated BB emissions were mixed with humidified zero air (Airgas Inc., Sparks, NV, USA) using a $4 \mathrm{~m}$ long spiral copper tubing $(12.7 \mathrm{~mm}$ OD). Before the mixing with $\mathrm{BB}$ emissions, the zero air was humidified by bubbling through Nanopure water in a glass $500 \mathrm{~mL}$ volume impinger. The flow rate was controlled by a mass flow controller (810C-CE-RFQ-1821, Sierra Instruments, Monterey, CA, USA). A Potential Aerosol Mass (PAM) Oxidation Flow Reactor (OFR; Aerodyne Research Inc., Billerica, MA, USA) was used to mimic approximately 7 days of atmospheric aging. The OFR consists of an alodine-coated aluminum cylinder ( $46 \mathrm{~cm}$ length and $22 \mathrm{~cm}$ diameter) with an internal volume of $13.3 \mathrm{~L}$. Two sets of UV lamps emit $\mathrm{UV}$ radiation at wavelengths of 185 and $254 \mathrm{~nm}$ (part numbers GPH436T5VH/4P and GPH436T5L/4P; Atlantic Ultraviolet Corporation, Hauppauge, NY, USA) in the OFR to produce ozone and $\mathrm{OH}$ radicals ( $\mathrm{Li}$ et al., 2015). UV irradiance in the OFR was quantified with a photodiode detector with wavelength range of 225-287 nm (TOCON_C6; sglux GmbH, Germany). Ultra-high purity nitrogen (Airgas Inc., Reno, NV, USA) was used to purge the UV lamp compartments to prevent the lamps from overheating. A probe that monitors relative humidity and temperature inside the OFR (from Aerodyne Inc., MA, USA) was mounted towards the outlet side of the OFR. A detailed characterization of

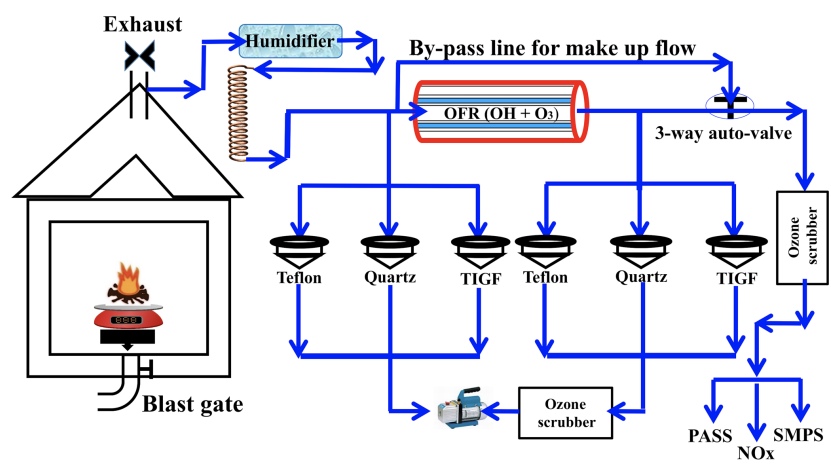

Figure 1. DRI Biomass Burning (BB) Facility with Oxidation Flow Reactor (OFR) and flow setup.

the OFR, including particle loss, $\mathrm{OH}$ production rate, and timescales of various processes, can be found in Bhattarai et al. (2018).

The duration of smoldering combustions was $58 \pm 27 \mathrm{~min}$ on average, whereas the average duration for flaming combustions was $22 \pm 8 \mathrm{~min}$. For both types of laboratory combustion experiments were both fresh (directly from the chamber) and aged (oxidized in the OFR) emissions continuously collected on separate sets of Teflon and pre-fired quartz filters, as well as on a TIGF filter followed by an XAD cartridge for detailed chemical analysis. Several online instruments were used to characterize gas- and particle-phase pollutants (see Fig. 1). The online instruments alternated every 10 min between sampling fresh and aged emissions using a computer-controlled three-way valve system. In this study, data collected with a chemiluminescence $\mathrm{NO}_{x}$ analyzer (Thermo-Environmental Instruments Inc., Franklin, MA 02038, USA) were synchronized with filter measurements. Maximum $\mathrm{NO}_{x}$ concentrations in fresh and aged BB emissions were measured consecutively.

A bypass flow was used to keep the flow from the BB chamber and through the OFR constant when online instruments switch between sampling fresh and aged emissions. To protect online instruments from high ozone concentrations produced in the OFR, ozone scrubbers were installed in front of the instruments' inlets. The ozone scrubbers were loaded with charcoal followed by Carulite 200 catalyst (Carus Corp., Peru, IL, USA).

All burning experiments, except for Siberian peat combustion, were conducted with $2.1 \mathrm{~V}$ of OFR voltage, which is equivalent to approximately 7 days of aging (Bhattarai et al., 2018). Since no replicates were collected during Siberian peat combustion, standard deviations and mean values were not calculated for these burns. Instead, during the combustion of Siberian peat, three different OFR voltages (3, 5, and $7 \mathrm{~V}$ ) were used to monitor the effect of enhanced oxidation with increasing OFR voltage and thus oxidants concentration. 


\subsection{Extraction procedure}

Teflon filters were extracted for 20 min under sonication in $30 \mathrm{~mL}$ of Nanopure water. The extracts were filtered with PTFE filters $(0.22 \mu \mathrm{m}$ pore size; Thermo Scientific, TN, USA); $20 \mathrm{~mL}$ of the extract was kept for further chemical analysis. For spectrophotometric analysis, $2 \mathrm{~mL}$ aliquots of each extract were used, and $8 \mathrm{~mL}$ aliquots were used for the solid-phase extraction (SPE) and further HULIS analysis. Prior to the SPE procedure, the $\mathrm{pH}$ of the aqueous aerosol extract was adjusted to 2 with $1 \mathrm{M} \mathrm{HCl}$ (Varga et al., 2001). This ensures retention of compounds with multiple polar functional groups (HULIS) in the SPE column (Kiss et al., 2002; Varga et al., 2001). At pH 2, all functional groups are expected to be protonated and less hydrophilic than at neutral $\mathrm{pH}(\sim 6-7)$. To remove the residue of inorganic constituents, SPE cartridges were rinsed with water and dried for $30 \mathrm{~min}$. The retained organics were eluted with $6 \mathrm{~mL}$ of methanol.

Hexane extracts were prepared using one-half of each of the quartz filter samples. Prior to hexane extraction, the filter halves were spiked with deuterated PAH standards needed for future chemical analysis of these extracts. The spiked quartz filters were extracted using an accelerated solvent extractor (ASE; DIONEX, ASE-300, Salt Lake City, UT, USA). Based on our analysis of over 300 compounds the recovery was more than $95 \%$. All hexane extracts were concentrated on a rotary evaporator (Rotavapor R-124, BÜCHI, New Castle, DE, USA) to $6 \mathrm{~mL}$. We used $2 \mathrm{~mL}$ of the concentrated hexane extract for spectrophotometric analysis (Lambda 1050, PerkinElmer, Waltham, MA, USA).

\section{$2.5 \mathrm{OC} / \mathrm{EC}$ analysis}

Samples collected on quartz-fiber filters were used to estimate total organic carbon $\left(\mathrm{OC}_{\text {Total }}\right)$ and elemental carbon (EC) mass. Punches $\left(\right.$ area $\left.=1.5 \mathrm{~cm}^{2}\right)$ from the quartz filter samples were analyzed with a thermal-optical carbon analyzer (Atmoslytic Inc., Calabasas, CA, USA) following the IMPROVE protocol (Chow et al., 1993, 2004). To obtain carbon content of hexane and water extracts separately, the approach of Lowenthal et al. (2009) was adopted. $30 \mu \mathrm{L}$ hexane extract aliquots were transferred to $7 \mathrm{~mm}$ diameter pre-baked quartz filter punches. The filter punches were dried for $24 \mathrm{~h}$ allowing the hexane to evaporate completely. The punches were then analyzed using the thermal-optical carbon analyzer to obtain the total OC content of the hexane extracts $\left(\mathrm{OC}_{\text {Hexane }}\right)$. To correct for the background, five blanks were prepared by spiking pre-baked filter punches with pure hexane and analyzed in the same way. Mean OC values of the blanks $\left(0.7, \mu \mathrm{g}\right.$ punch $\left.{ }^{-1}\right)$ were subtracted from total $\mathrm{OC}_{\text {Hexane }}$ values (on average $2.4 \mu \mathrm{g} \mathrm{punch}^{-1}$ for all fuels). The OC mass of the hexane extract $\mathrm{OC}_{\text {Hexane }}$ (in $\mathrm{g} \mathrm{mL}^{-1}$ ) was subtracted from the total $\mathrm{OC}$ mass $\left(\mathrm{OC}_{\text {Total }}\right)$, yielding the $\mathrm{OC}$ mass of the polar $\mathrm{OC}$ fraction $\left(\mathrm{OC}_{\text {Water }}\right)$ under the assump- tion that compounds which are not soluble in hexane are water soluble.

\subsection{Spectrophotometer analysis}

Spectrophotometric characterization of water, hexane, and water extracts after SPE (HULIS fraction in methanol) were performed with a UV-Vis spectrophotometer (Lambda 1050, PerkinElmer, Waltham, MA, USA) in $10 \mathrm{~mm}$ path length quartz macro cuvettes (FireflySci Inc., NY, USA). Absorption spectra were taken over the $190-900 \mathrm{~nm}$ wavelength range. The spectrophotometer was operated with a reference cell, filled with the corresponding blanks: pure water for water extracts, hexane with PAH standards for hexane extracts, and methanol for SPE extracts. The use of corresponding blanks in the reference cell helped to eliminate/subtract absorption caused by solvents and internal standards. Results are reported in terms of absorbance $A$, defined as $A=\log$ $I_{0} / I$ (where $I_{0}$ is the radiant power of incident light and $I$ is the radiant power of transmitted light) and related to the transmittance $T$ by $A=-\log _{10} T$, to the optical depth $\tau$ by $A=\tau / \ln 10$. The relation between absorbance at each wavelength $A_{\lambda}$ and the fractional volume concentration of the analytes $(c)$ is given by Eq. (1a) where $\epsilon$ is absorption coefficient and $l$ is length of cuvette $(1 \mathrm{~cm})$.

$A_{\lambda}=\epsilon c l$

Extinction coefficient can be calculated rearranging Eq. (1) as

$\epsilon=\frac{A_{\lambda}}{c l}$.

In order to account for instrumental background drift that was observed in the wavelength range of 700 and $900 \mathrm{~nm}$, a baseline correction was performed using the Hecobian et al. (2010) approach. The mean absorbance $A_{\text {Mean (700-900) }}$ was calculated in the wavelength range of 700 to $900 \mathrm{~nm}$ and then the mean absorbance value was subtracted from the absorbance values for each individual wavelength $A_{\lambda}$ to yield the baseline-corrected absorbance $\mathrm{Abs}_{\lambda}$ as

$\operatorname{Abs}_{\lambda}=\left(A_{\lambda}-A_{\text {Mean }}(700-900)\right)$.

It is important to consider how the absorbance values are contributing to solar radiative forcing estimates. Clear sky total spectral solar irradiance on a tilted receiver plane $\left(\mathrm{GTIR}_{\lambda}\right)$ was determined with the Simple Model of Atmospheric Radiative Transfer of Sunshine (SMARTS) program (Gueymard, 1995). The normalized spectral irradiance of the solar radiation was multiplied with obtained absorbance spectra for all extracts to estimate solar-weighted absorbance $\left(\left[\mathrm{Abs}_{\lambda}\right]_{\mathrm{SW}}\right)$.

$\left[\operatorname{Abs}_{\lambda}\right]_{\mathrm{SW}}=\operatorname{Abs}_{\lambda} \times \frac{\mathrm{GTIR}_{\lambda}}{\sum_{290}^{900} \operatorname{GTIR}_{\lambda}}$ 
The total absorbance (TotalAbs) was calculated by integrating solar-weighted absorbance from 190 to $900 \mathrm{~nm}$ and normalizing it with respect to the total consumed fuel mass during each burning experiment. To compare the total absorbance between different extracts, all dilution factors were taken into account.

TotalAbs $=\frac{\sum_{290}^{900}\left[\mathrm{Abs}_{\lambda}\right]_{\mathrm{SW}}}{\text { fuel mass consumed }}$

We performed two-tailed pairwise $t$ tests on sets of fresh and photochemically aged (with OFR) aerosols in different extracts to evaluate the statistical implications of our results. We computed the $t$ statistic under the null hypothesis of "no change in absorption took place upon aging/oxidation". All $p$ values from the statistic are reported in Table S2 (Supplement).

In order to estimate the absorption efficiency of the extracts, measured absorption $\left(\mathrm{Abs}_{\lambda}\right.$; Eq. 1c) was used to calculate the mass absorption coefficients (MACs) for both hexane ( $\left.\mathrm{MAC}_{\text {Hexane }}\right)$ and water extracts $\left(\mathrm{MAC}_{\text {Water }}\right)$ :

$\mathrm{MAC}_{\text {Hexane }}=\left\{\left[\mathrm{Abs}_{\lambda}\right]_{\mathrm{SW}}\right\}_{\text {Hexane }} / \mathrm{OC}_{\text {Hexane }}$,

$\mathrm{MAC}_{\text {Water }}=\left\{\left[\mathrm{Abs}_{\lambda}\right]_{\mathrm{SW}}\right\}_{\text {Water }} / \mathrm{OC}_{\text {Water }}$,

where $\left[\mathrm{Abs}_{\lambda}\right]_{\mathrm{SW}}$ is the solar-weighted absorbance, $\mathrm{OC}_{\text {Hexane }}$ is the organic carbon mass of the hexane-extracted fraction and $\mathrm{OC}_{\text {Water }}$ is the organic carbon mass from the waterextracted $\mathrm{OC}$ fraction.

The solar-weighted MAC values $\left(\mathrm{MAC}_{\mathrm{sw}}\right)$ for individual wavelengths were integrated over the entire spectral range yielding spectrally integrated solar-weighted mass absorption efficiency or SIMAC $_{\text {sw }}$.

Absorption spectra often can be approximated by a power law with a single exponent, the so-called absorption Ångström exponent (AAE), quantifying the wavelength dependence of the absorbance as

$\frac{\operatorname{Abs}_{\lambda 2}}{\operatorname{Abs}_{\lambda 1}}=\left[\frac{\lambda 1}{\lambda 2}\right]^{\mathrm{AAE}}$,

where $\operatorname{Abs}_{\lambda}$ is the absorbance at the corresponding wavelength $\lambda$. To calculate AAE, Eq. (8) can be written as

$\mathrm{AAE}=-\frac{\ln \left(\mathrm{Abs}_{\lambda 2}\right)-\ln \left(\mathrm{Abs}_{\lambda 1}\right)}{\ln (\lambda 2)-\ln (\lambda 1)}$,

where one can clearly see that AAE is the negative slope of absorbance plotted as function of wavelength in log-log space (Moosmüller et al., 2011). Here, we use the AAE values for three different wavelength ranges (1) $200-400 \mathrm{~nm}$, (2) 400-600 nm, (3) 600-900 nm, each derived with linear regression in $\log -\log$ space. Absorbance data in the 600$900 \mathrm{~nm}$ range were quite noisy; therefore, we averaged sets of ten data points, thereby reducing the number of data points from 300 to 30 and obtaining AAE from a linear regression of these points in $\log -\log$ space. We determined AAE values for extracts of fresh and aged aerosol emission from the combustion of several different fuels.

The imaginary part of the bulk refractive index was calculated for water extracts. MAC values computed from spectrophotometer analysis were multiplied by mass density $(\rho)$ of the aerosols (see Eq. 8) to obtain absorption coefficients $(\beta)$ such as used in Mie theory (Sun et al., 2007).

$\beta=\rho \mathrm{MAC}_{\mathrm{water}}$

The mass density of bulk aerosol depends on fuel type and burning condition. In this work, instead of making an attempt to measure aerosol density for all fuel types (and both fresh and aged aerosols), we assumed a general $\mathrm{BrC}$ aerosol mass density of $1569 \mathrm{~kg} \mathrm{~m}^{-3}$ (Hoffer et al., 2006) for all BB aerosols from our experiments. The bulk absorption coefficient $\beta$ is related to the imaginary part of the refractive index (k) (Moosmüller et al., 2009) as

$\beta=\frac{4 \pi k}{\lambda}$,

and the imaginary part of the refractive index $k$ can be written as

$k=\frac{\beta \lambda}{4 \pi}$.

Total imaginary refractive index $k_{\text {total }}$ was computed by using a simple volume mixing rule as

Hexane fraction $(\mathrm{HF})=\frac{\mathrm{OC}_{\text {Hexane }}}{\mathrm{OC}_{\text {Hexane }}+\mathrm{OC}_{\text {Water }}}$,

Water fraction $(\mathrm{WF})=\frac{\mathrm{OC}_{\mathrm{water}}}{\mathrm{OC}_{\text {Hexane }}+\mathrm{OC}_{\text {Water }}}$,

$k_{\mathrm{total}}=\mathrm{HF} \cdot k_{\text {Hexane }}+\mathrm{WF} \cdot k_{\mathrm{water}}$,

under the assumption that $\mathrm{OC}_{\mathrm{Hexane}}$ and $\mathrm{OC}_{\text {Water }}$ have the same mass density.

\subsection{Ultrahigh-resolution mass spectrometry}

Water-soluble organic carbon (WSOC) was extracted from quartz fibre filter punches in $5 \mathrm{~mL}$ of HPLC grade water using $1.5 \mathrm{~h}$ low-speed orbital shaking. The extracts were filtered using $0.2 \mu \mathrm{m}$ pore-size PTFE syringe filters (Puradisc 25, Whatman plc, Maidstone, UK) and acidified to $\mathrm{pH} 2$ using $1 \mathrm{M} \mathrm{HCl} .30 \mathrm{mg}$ Strata-X cartridges (Phenomenex Inc., Torrance, CA, USA) were used to isolate high molecular weight water-soluble organic carbon from the aqueous extracts. The retained WSOC was eluted twice from the Strata-X cartridges: first with $1 \mathrm{~mL}$ of methanol and water $(90 / 10 v / v)$ and second with $1 \mathrm{~mL}$ of methanol containing 
$0.3 \%$ of aqueous ammonia. Both extracts were combined and the volume was reduced to $1 \mathrm{~mL}$ under a gentle stream of nitrogen. The WSOC described in this paper is operationally defined as the WSOC that is both retained and recovered from the SPE cartridges (SPE recovered), thus it is not identical to the total WSOC. Samples were analyzed using an ultrahigh-resolution Orbitrap Elite mass spectrometer (Thermo Fisher Scientific, Waltham, MA, USA) equipped with a heated electrospray ionization (HESI) source. Mass spectrometer settings for negative HESI included heater temperature of $100^{\circ} \mathrm{C}$, spray voltage of $2.75 \mathrm{~V}$, and capillary temperature of $270^{\circ} \mathrm{C}$. Mass spectra were recorded for $m / z 100$ to 700 with the resolving power 240000 at $m / z 400$. The observed negative ions are expected to have formed by a deprotonation reaction. This implies that only structures with polar functional groups (e.g., carboxyl, hydroxyl) can be observed. The molecular formulas for singly charged ions were assigned using an empirical formula calculator (Sierra Analytics Composer64, Modesto, CA, USA). The calculator uses the Kendrick mass defect to sort homologous ion series (species with a given double bond equivalents, DBE, and heteroatom content but differing by increments of $-\mathrm{CH}_{2}$ ). The calculator was set to allow up to 200 carbon, 1000 hydrogen, 30 oxygen, 3 nitrogen, and 1 sulfur atoms per elemental composition. Additional method details were described in Mazzoleni et al. (2010) and Putman et al. (2012).

\section{Results and discussion}

There are two common problems associated with estimation of light-absorbing properties of BrC. First, in BB emissions, $\mathrm{OC}$ containing $\mathrm{BrC}$ is generally mixed with $\mathrm{BC}$, except for pure smoldering combustion such as encountered for combustion of peat fuels that emits nearly exclusively OC. Therefore, it is often challenging to distinguish between light absorption by $\mathrm{BC}$ and by $\mathrm{BrC}$, especially if the $\mathrm{BC}$ concentrations are high (e.g., for flaming combustion). Second, most online instruments use 1-7 fixed wavelengths for light absorption measurements (Drinovec et al., 2015, 2017; Lewis et al., 2008; Virkkula et al., 2005), which may not be sufficient to fully characterize spectral absorption properties of BB BrC emissions (Andreae and Gelencsér, 2006).

In contrast to online instruments, the approach used in this study - measurements of $\mathrm{BrC}$ light absorption in extracts - eliminates the interference of $\mathrm{BC}$ absorption and allows recording high-resolution (i.e., $\sim 1 \mathrm{~nm}$ ) absorption spectra over a large wavelength range (i.e., 190-900 nm, for this work).

\subsection{Comparison of absorbance}

Figure 2 shows absorbance spectra measured for water (Fig. 2a) and hexane (Fig. 2b) extracts of fresh and aged $\mathrm{BB}$ emissions from two fuels (Florida peat, FASMEE). Ab-
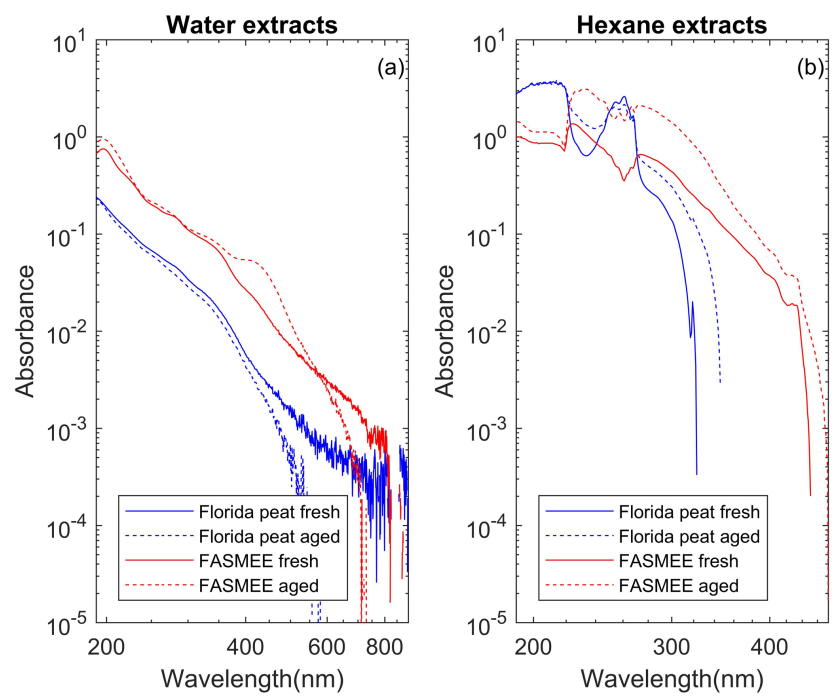

Figure 2. Light absorbance spectra of water (a) and hexane (b) extracts from representative samples of biomass-burning emissions from two representative fuels. Solid and dashed lines correspond to fresh and aged BB emissions, respectively.

sorbance data measured with the spectrophotometer were plotted on a $\log -\log$ scale for easier visualization of AAE (Eq. 6), directly displaying AAE as negative slope and curvature representing deviations from the power law.

Absorbance of fresh and aged emissions varied between fuels and the spectrophotometer signal was noisy above a wavelength of $600 \mathrm{~nm}$. For peat samples (e.g., Florida peat), absorbance of both fresh and aged water extracts decreased steadily towards longer wavelengths but we did not observe such steady decrease for the hexane extract; instead fluctuations were observed even at the shorter wavelengths. The absorbance of aged BBOA is less than fresh BBOA for water extracts but for the aged BBOA hexane extract, the absorbance was higher than that of the fresh hexane extract close to $250 \mathrm{~nm}$. In the case of the fuels that undergo flaming combustions (e.g., FASMEE), the absorbance from aged BBOA water extracts were lower than that of the fresh BBOA water extracts at longer wavelengths $(>600)$; in addition, an increase in the absorbance was observed in the $450-500 \mathrm{~nm}$ wavelength range. Absorbance values for aged BBOA hexane extract of FASMEE fuel were higher than fresh BBOA at all wavelengths. The increase of absorbance for FASMEEaged BBOA can be attributed to the type of combustion (see Supplement). For better quantitative comparison, total solar-weighted absorbance and MAC values are compared in Sects. 3.2, 3.4, and 3.6.

\subsection{Absorbance of polar and non-polar fractions}

To compare the contribution of polar and non-polar fractions to the light absorbance, the following steps were taken. Wavelength-dependent absorbance of each extract was recal- 


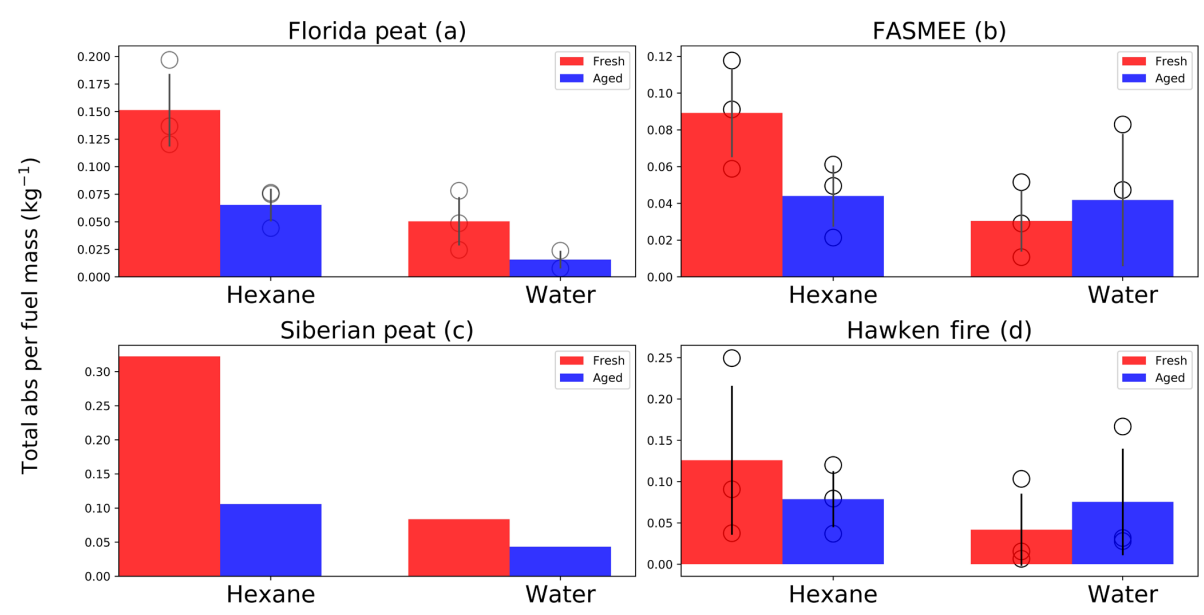

Figure 3. Comparison of total absorbance (Eq. 3) per fuel mass consumed for fresh and aged aerosols in water and hexane extracts, normalized to $1 \mathrm{~mL}$ extraction volumes. Bars, circles, and error bars represent the mean values, individual observations, and standard deviations, respectively. No error bars are given for Siberian peat, because only one experiment was performed with this fuel.

culated using the Beer-Lambert law to that of a solution that would have been obtained if the collected aerosol was extracted in $1 \mathrm{~mL}$ of solvent. This was necessary to account for variations in solvent volumes used for aerosol extraction (Sect. 2.4). Figure 3 shows the normalized absorbance for polar and non-polar extracts of fresh and aged BB aerosols. While most previous studies have focused on light absorption by the water-soluble fraction of BB aerosols (Hecobian et al., 2010; Xie et al., 2017; Zhang et al., 2013), very little attention has been given to the light absorption by the water-insoluble part of BB aerosols (Chen and Bond, 2010). Our results demonstrate that for fresh aerosols from all fuels, non-polar (hexane) extracts absorb more than polar (water) extracts (Fig. 3). For fresh aerosols, the ratios of TotalAbs in the hexane extract to the water extract are 3.00 (Florida peat), 2.92 (FASMEE), and 3.01 (Hawken Fire). This $\sim 3$ fold higher light absorption of the non-polar fraction (hexane extract) necessitates a detailed chemical speciation analysis to yield further insight into the light-absorbing compounds that can be found in the non-polar fraction.

Figure 3 shows the absorbance of fresh samples with red bars and aged samples with blue bars. Aging in the OFR changed light absorption properties for BB aerosol extracts for all four fuels, even though there is a significant variability among replicate measurements (shown as points in Fig. 3). For Florida peat combustion, the total absorbance per consumed fuel mass of aerosol hexane extracts decreased from $0.15 \mathrm{~kg}^{-1}$ for fresh aerosol to $0.065 \mathrm{~kg}^{-1}$ for aged aerosol. Absorbance of Florida peat combustion water extracts decreased by an even larger factor due to aging (from 0.05 to $0.015 \mathrm{~kg}^{-1}$ ). A similar trend was observed for Siberian peat combustion extracts, where absorbance in the hexane extracts decreased due to aging from 0.058 to $0.032 \mathrm{~kg}^{-1}$, while for the water extracts this decrease was from 0.084 to $0.043 \mathrm{~kg}^{-1}$. In contrast, light absorbance in water extracts of aged BBOA from FASMEE and Hawken Fire fuels increased due to aging from 0.03 to $0.042 \mathrm{~kg}^{-1}$ and from 0.042 to $0.079 \mathrm{~kg}^{-1}$, respectively. No increase in absorbance due to aging was observed for hexane extracts of FASMEE and Hawken Fire fuel combustion aerosols, where absorbance decreased from 0.089 to $0.044 \mathrm{~kg}^{-1}$ (FASMEE) and from 0.13 to $0.079 \mathrm{~kg}^{-1}$ (Hawken Fire).

To estimate if the difference in absorbance values between fresh and aged aerosol extracts is statistically significant, the Student pairwise $t$ test was used at $p=0.05$. The $p$ values from the pairwise $t$ test for hexane extracts showed statistical significance for Florida peat $(p=0.04)$, and FASMEE fuel $(p=0.016)$. No statistically significant difference was observed in the case of the Hawken Fire $(p=0.442)$. For Siberian peat we could not perform a statistical significance test since no replicates were collected. The $p$ values computed for all water extracts showed no statistical difference in absorbance between fresh and aged aerosol extracts $(p>0.16)$. Given the high variability in the observed absorbance values among individual burns, it is possible that a larger number of experiments would have better constrained the effect of aging on absorbance. However, given the resources available for this study, it was not possible to collect more replicate samples. Moreover, the $p$ values are higher for the emissions from the flaming fuels (e.g., 0.442 for Hawken Fire fuel combustion emissions in hexane extract) compared to the smoldering fuels (e.g., 0.04 for Florida peat combustion emissions in hexane extract).

The light absorption properties of polar extracts are different for OFR-aged emissions from peat and forest fuels (Fig. 3). While aging decreased the total absorbance of the polar fraction for peat fuels, the opposite was observed for forest fuels. The increase in light absorption of forest fuel emissions is mainly due to the increase in absorption in the $380-500 \mathrm{~nm}$ range (Fig. 2). This suggests the formation of 


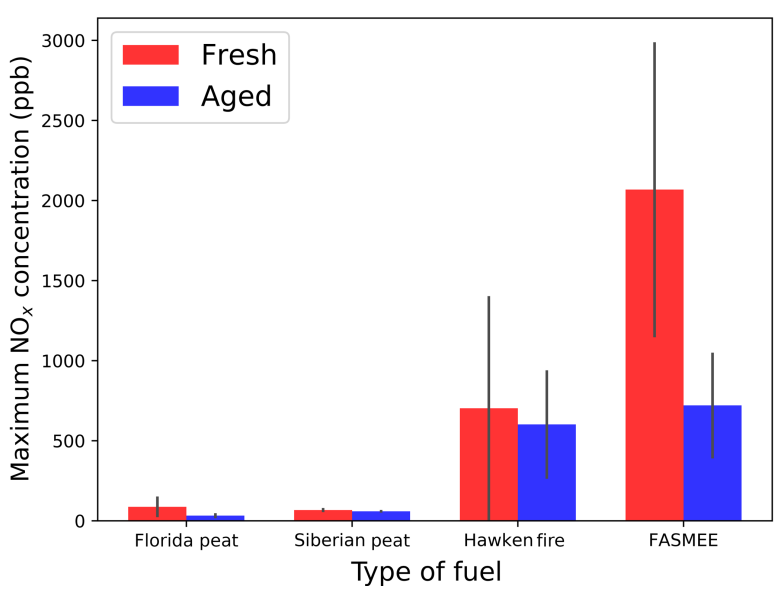

Figure 4. Maximum $\mathrm{NO}_{x}$ concentration for emissions from the combustion of different fuels. Average values from replicates plotted as bars; error bars are standard deviations of the mean from three replicate burnings for each fuel.

new organic substances that absorb light in this range. Flaming fuels typically had emissions with higher $\mathrm{NO}_{x}$ concentration than smoldering fuels (Fig. S2). The presence of $\mathrm{NO}_{x}$ may lead to the formation of nitrogen-containing aromatic compounds during aerosol aging (Kahnt et al., 2013; Kitanovski et al., 2012). These compounds can absorb in the 450-550 $\mathrm{nm}$ range (J. Liu et al., 2016) and, therefore, can cause an absorbance increase in this spectral range. High $\mathrm{NO}_{x}$ emissions observed during the combustion of FASMEE and Hawken fire fuels may be explained by two phenomena: elemental composition of fuel and high temperature burning conditions. Both the FASMEE and Hawken fire fuels had leaves and branches, which may result in greater nitrogen content compared to peats where most of the nitrogenous compounds are bacterially decomposed during peat formation (Reddy and DeLaune, 2008) leaving only carbon and oxygen in the refractory fraction of peat.

\subsection{Effect of $\mathrm{NO}_{x}$ on aged aerosol}

$\mathrm{NO}_{x}$ concentrations reach their maximum in the beginning of each burn (Fig. S2). Figure 4 shows maximum $\mathrm{NO}_{x}$ concentrations for the combustion of each fuel. In the case of flaming fuels (Hawken Fire and FASMEE), the maximum $\mathrm{NO}_{x}$ concentrations were up to 800 and $2000 \mathrm{ppb}$, respectively. In the case of peat fuels (Florida and Siberian), $\mathrm{NO}_{x}$ concentrations did not exceed $100 \mathrm{ppb}$. This difference is probably due to a much faster fuel consumption rate in higher temperature during flaming combustion $\left(\sim 5.33 \mathrm{~g} \mathrm{~min}^{-1}\right)$ than smoldering combustion of peats $\left(\sim 0.83 \mathrm{~g} \mathrm{~min}^{-1}\right)$ (Fig. S1).

We suspect that high $\mathrm{NO}_{x}$ concentrations affect formation of nitrogen-containing secondary organic aerosols (SOAs; Laskin et al., 2009; Lin et al., 2015, 2017). The effect of $\mathrm{NO}_{x}$ on the formation of SOA has been highly debated and not sufficiently explored to date. However, experimental cham- ber studies with representative precursors (Kleindienst et al., 2004; J. Liu et al., 2016) and model estimates based on ambient measurements (Henze et al., 2008) provide compelling evidence in favor of increasing SOA yields in the presence of $\mathrm{NO}_{x}$. The mechanism for SOA formation varies with organic precursor type and the amount of $\mathrm{NO}_{x}$ present $(\mathrm{Ng}$ et al., 2007a, b, 2008). Nitro-organic compounds, especially nitro-aromatic compounds, are abundant in the atmosphere and can be used as a tracer for biomass-burning emissions (Iinuma et al., 2010). Previous studies on the evolution of SOA in the presence of $\mathrm{NO}_{x}$ mostly focused on total SOA yields, without investigating light absorption properties and compositional variability. Recently, J. Liu et al. (2016) estimated the effect of photochemical aging in the presence of $\mathrm{NO}_{x}$ on light absorption properties of aerosols produced from different primary OA precursors. They reported a large increase in the MAC values in the 300 to $500 \mathrm{~nm}$ wavelength range for SOA derived from aromatic precursors in a $\mathrm{NO}_{x}$ rich environment compared to $\mathrm{NO}_{x}$-free conditions. Interestingly, there was no distinct change in the MAC values for SOA derived from aliphatic precursors under high $\mathrm{NO}_{x}$ conditions. We observed an increase in absorbance values in the range of 380 to $580 \mathrm{~nm}$ for the FASMEE fuel's aerosol water extract (Fig. 2), which is in agreement with J. Liu et al. (2016) results.

In order to confirm the presence of newly formed nitrogencontaining SOA during OFR oxidation, the high molecular weight fraction of aqueous extracts of fresh and aged BB samples were analyzed using ultrahigh-resolution Orbitrap Elite mass spectrometry. We assigned $\mathrm{CHO}, \mathrm{CHNO}$, CHOS, and CHNOS molecular formulas to the ions detected in the electrospray negative ion mode. Figure 5 shows the difference mass spectra of the assigned molecular formulas for the fresh and aged BB emissions of the analyzed fuels. For each fuel sample, the normalized relative abundances of the aged emissions were subtracted from the normalized relative abundances of fresh BB emissions. Thus, the signals with positive relative abundances represent the prominent molecular formulas of fresh $\mathrm{BB}$ emissions, while signals with negative relative abundances represent the prominent molecular formulas for the aged emissions. No prominent CHNO molecular formulas were detected in the OFRaged aerosol from the combustion of Siberian and Florida peat fuels (Fig. 5a, b). However, a large number of CHNO species were detected in the OFR-aged aerosol from the combustion of the FASMEE and Hawken fire fuels (Fig. 5c, d). This result suggests that $\mathrm{CHNO}$ organic compounds were formed during the aging/oxidation process of flaming combustion emissions from FASMEE and Hawken fire fuels. These observations are consistent with the hypothesis that organic nitrogen compound formation occurs during the oxidative aging of flaming combustion fuels when the concentration of nitrogen oxides was high (Fig. 5). DBEs can increase with aging because non-polar aromatic species may become partially oxidized facilitating their ionization in the 
Negative ion difference spectra
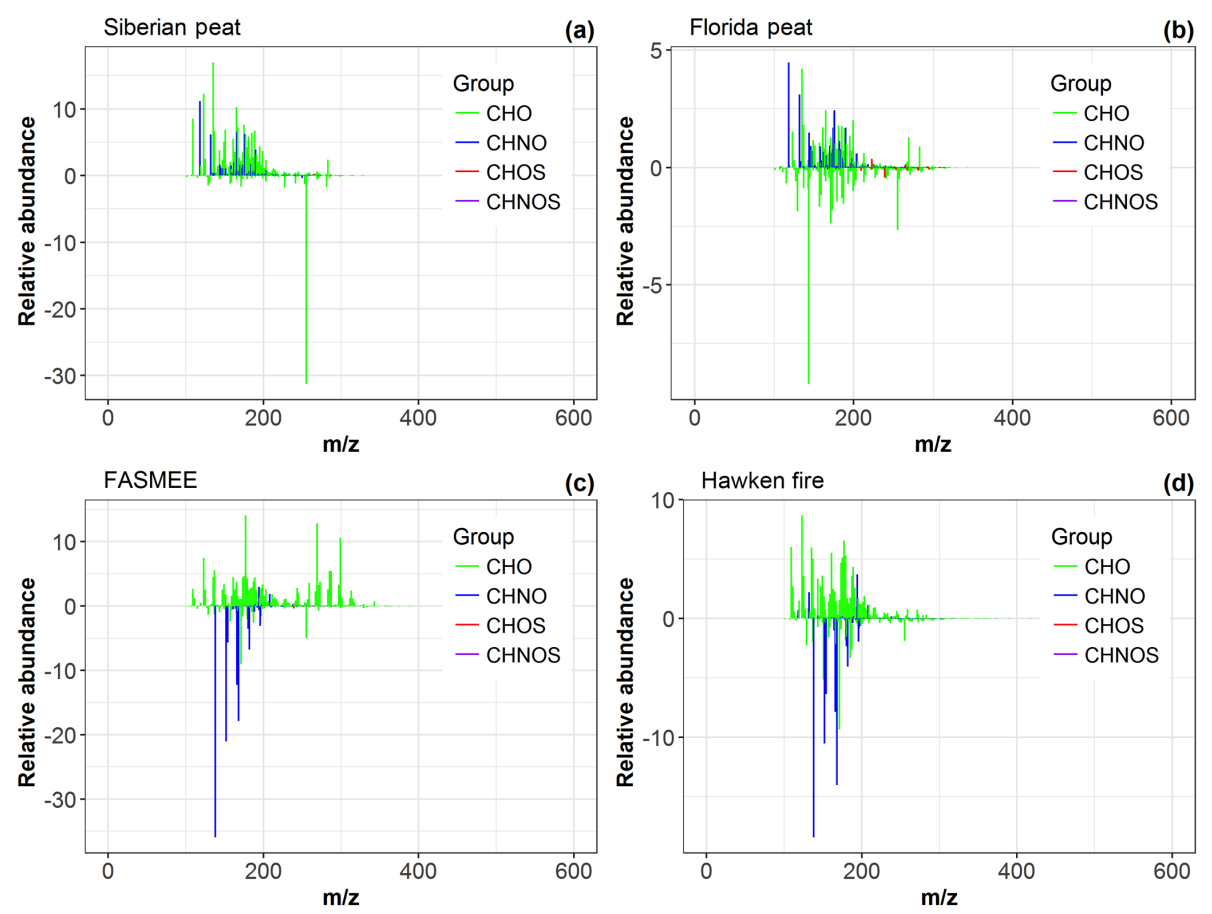

Figure 5. Ultrahigh-resolution mass spectrometry difference mass spectra for WSOC from the combustion emissions from the combustion of the representative fuels. (a, b) - smoldering fuels (peats); (c, d) - flaming fuels.

aged samples. Although CHNO species were formed in the peat fire combustion experiments, in contrast to the flaming fuel experiments, we did not observe them in high relative abundances nor did we observe a large number of uniquely formed species in the aged extracts.

\subsection{Light absorption by humic-like substances (HULIS)}

It has been reported that high molecular weight organic species (or HULIS) comprise a substantial fraction of watersoluble organic aerosols (Graber and Rudich, 2006). HULIS can originate in the atmosphere either from primary emissions (Lin et al., 2010) or via oligomerization of primary precursors during SOA formation (Samburova et al., 2005). HULIS can play a significant role in hygroscopic growth and cloud condensation nuclei activity of ambient aerosols (Dinar et al., 2006; Gysel et al., 2004). In addition, solar light absorption by HULIS is of special interest with respect to its impact on direct aerosol radiative forcing and climate change (Hoffer et al., 2006). We isolated the HULIS fraction from water extracts using the SPE approach. In this study, HULIS fractions isolated from water extracts of fresh and aged BB emissions were characterized with UV-Vis spectrophotometry and compared with the spectra of the total water-soluble extracts (Fig. 6). The total solar-weighted absorbance per fuel mass consumed for HULIS (e.g., for fresh Florida peat:
$0.14 \mathrm{~kg}^{-1}$ ) is mostly lower compared to the total absorbance per fuel mass consumed for water extracts (e.g., for fresh Florida peat: $0.5 \mathrm{~kg}^{-1}$ ), except for Hawken fire fuel.

Hawken fire fuel was mostly comprised of cheatgrass and shrubs, characteristic of the semi-arid lower slopes of the Carson Range of the Sierra Nevada, USA. For the fresh Hawken fire BBOA, the total absorbance per fuel mass consumed of the HULIS fraction isolated from the water extract was $0.038 \mathrm{~kg}^{-1}$, whereas that of water extract overall was $0.041 \mathrm{~kg}^{-1}$ (Fig. 6). This shows that light absorption by water-soluble compounds emitted from the Hawken fire was dominated $(\sim 92 \%)$ by high molecular weight organic species (HULIS). We also noticed that the total solar-weighted absorbance for water extract of fresh Hawken fire BBOA $\left(0.041 \mathrm{~kg}^{-1}\right)$ (Fig. 6d) increased by $\sim 83 \%\left(0.075 \mathrm{~kg}^{-1}\right)$ (Fig. 6d) after aging. At the same time, a distinct decrease in the absorbance of the HULIS fraction $(\sim 42 \%)$ was observed upon aging (from 0.038 to $\left.0.022 \mathrm{~kg}^{-1}\right)$. Although the points are variable $(p>0.4)$, the decreased absorbance of the HULIS fraction indicates that there may be a greater contribution from lower molecular weight species after oxidation of the Hawken fire BBOA.

Both fresh and aged BBOA from the FASMEE fuel show the HULIS fraction absorbance is $30 \%$ to $40 \%$ of the total water-soluble fraction of aerosol (Fig. 6b). For Siberian peat, the HULIS fraction absorbance was $50 \%$ to $55 \%$ of the total water-soluble fraction (Fig. 6c), for both the fresh and aged 


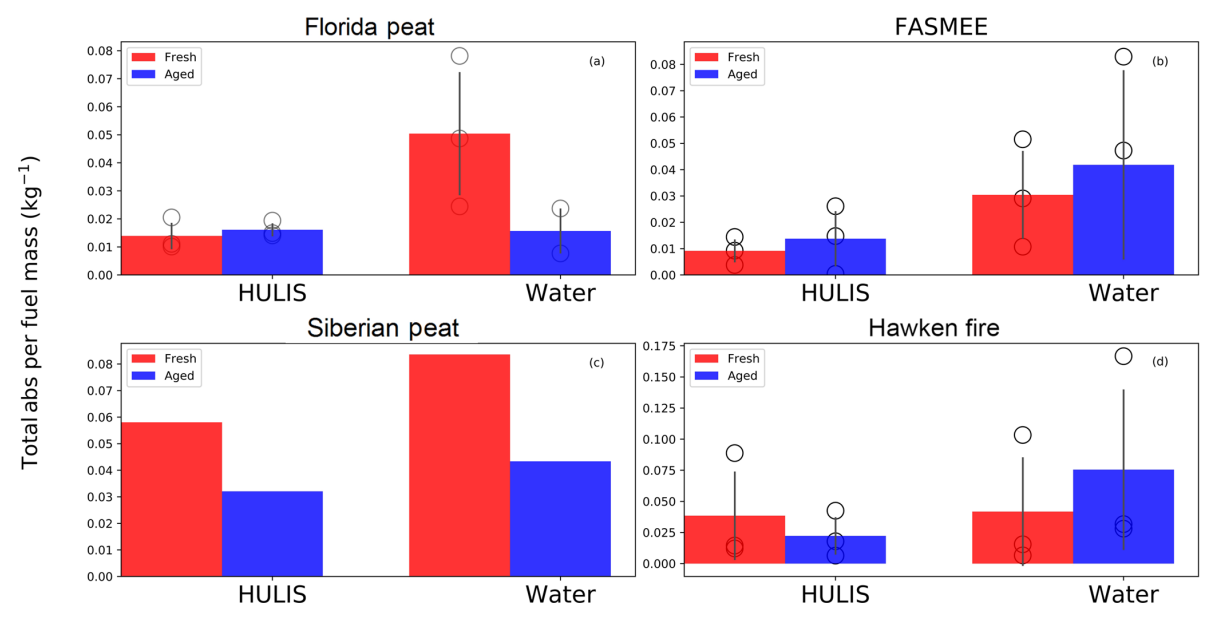

Figure 6. Comparison of total absorbance per fuel mass consumed for fresh and aged aerosols in water and HULIS extracts, normalized to $1 \mathrm{~mL}$ extraction volumes. Bars, circles, and error bars represent the mean values, individual observations, and standard deviations, respectively. No error bars are given for Siberian peat, because only one experiment was performed with this fuel.

BBOA. The large fraction of HULIS absorption compared to the total water-soluble BBOA from all fuels necessitates detailed chemical characterization. For Florida peat, the total absorbance of the HULIS fraction increased by only $~ 16 \%$ (from 0.139 to $0.161 \mathrm{~kg}^{-1}$ ) and this was not statistically significant $(p=0.68)$. For the FASMEE fuel, the increase in the total absorbance of "fresh" HULIS $\left(0.091 \mathrm{~kg}^{-1}\right)$ after OFR oxidation $\left(0.138 \mathrm{~kg}^{-1}\right)$ was also not statistically significant $(p=0.54)$.

\subsection{Effect of pH}

Light absorption by water-soluble ambient $\mathrm{BrC}$ was shown to depend on $\mathrm{pH}$ (Phillips et al., 2017). In our experiments, the $\mathrm{pH}$ of biomass-burning water extracts ranged from 6.2 to 6.4. However, atmospheric aerosol $\mathrm{pH}$ often ranges from 0.5 to 3 (Bougiatioti et al., 2016; Weber et al., 2016). Atmospheric processing and mixing with acidic aerosols could decrease the $\mathrm{pH}$ of $\mathrm{BB}$ aerosols and thus affect their light absorption properties. To investigate the effect of $\mathrm{pH}$ on light absorption for our BBOA water extracts, we performed a series of experiments in which these extracts were acidified to $\mathrm{pH}=2$.

As $\mathrm{pH}$ was decreased from $\sim 6.3$ to 2 , a decrease in absorbance was observed for BBOA water extracts from all fuels, and this decrease was more distinguishable towards longer wavelengths ( $>500 \mathrm{~nm}$; see Fig. S4). It was reported in the literature (Teich et al., 2017; Zhao et al., 2015) that BB aerosols contain organic compounds with aromatic functional groups. At lower $\mathrm{pH}$, protonation of functional groups occurs and could be the potential reason for the decrease in absorbance. The decrease in absorption with decrease of $\mathrm{pH}$ was also observed by Phillips et al. (2017) for atmospheric ambient aerosols. A similar absorption reduction in the ultraviolet and visible region of the spectrum was reported for soil humic acid (Tsutsuki and Kuwatsuka, 1979) and fulvic acid (Baes and Bloom, 1990) extracts.

In the present study, we found that for the fresh BBOA, the total absorbance (per fuel mass) decreases with the decrease in $\mathrm{pH}$ for all fuels (e.g., fresh Florida peat: from 0.05 to $0.033 \mathrm{~kg}^{-1}$ ), except for the Hawken fire fresh BBOA, where a small increase the in total absorbance values (from 0.042 to $0.049 \mathrm{~kg}^{-1}$ ) was observed (Fig. 7). However, the $p$ values (0.21 for Florida peat, 0.27 for FASMEE, 0.094 for Hawken fire) from a pairwise $t$ test do not permit any definitive conclusions about the effect of $\mathrm{pH}$ on light absorption. The total absorbance values also decreased (e.g., FASMEE: from 0.042 to $0.019 \mathrm{~kg}^{-1}$ ) for all of the aged BBOA, but these changes were also not statistically significant $(p>0.3)$.

As was discussed above, we have observed the increase in absorbance between fresh and aged neutral water extracts $(\mathrm{pH}=6.2-6.4)$ for flaming fuels (e.g., Hawken fire: from 0.042 to $0.076 \mathrm{~kg}^{-1}, p$ value $=0.158$ ). However, for the acidified water extracts $(\mathrm{pH}=2)$ of BBOA from flaming fuels, a decrease in the absorbance between fresh and aged BBOA was observed (e.g., Hawken fire: from 0.049 to $\left.0.039 \mathrm{~kg}^{-1}\right)$, though this change was not statistically significant $(p=0.44)$.

\subsection{Light absorption efficiency of polar and non-polar extracts}

Figure 8 shows the SIMAC $_{\mathrm{sw}}$ values of hexane and water extracts of fresh and aged aerosols produced by combustion of the four fuels. SIMAC $\mathrm{Sw}_{\mathrm{sw}}$ values, which describe mass-based light absorption efficiency, were calculated using the equations provided in Sect. 2.6. In general, SIMAC $_{\mathrm{Sw}}$ values for fresh emission from all fuels were greater for the water extracts than for the hexane extracts, except for the Siberian peat BBOA. The highest SIMAC $_{\mathrm{sw}}$ values $\left(\sim 2.8 \mathrm{~m}^{2} \mathrm{~g}^{-1}\right)$ 


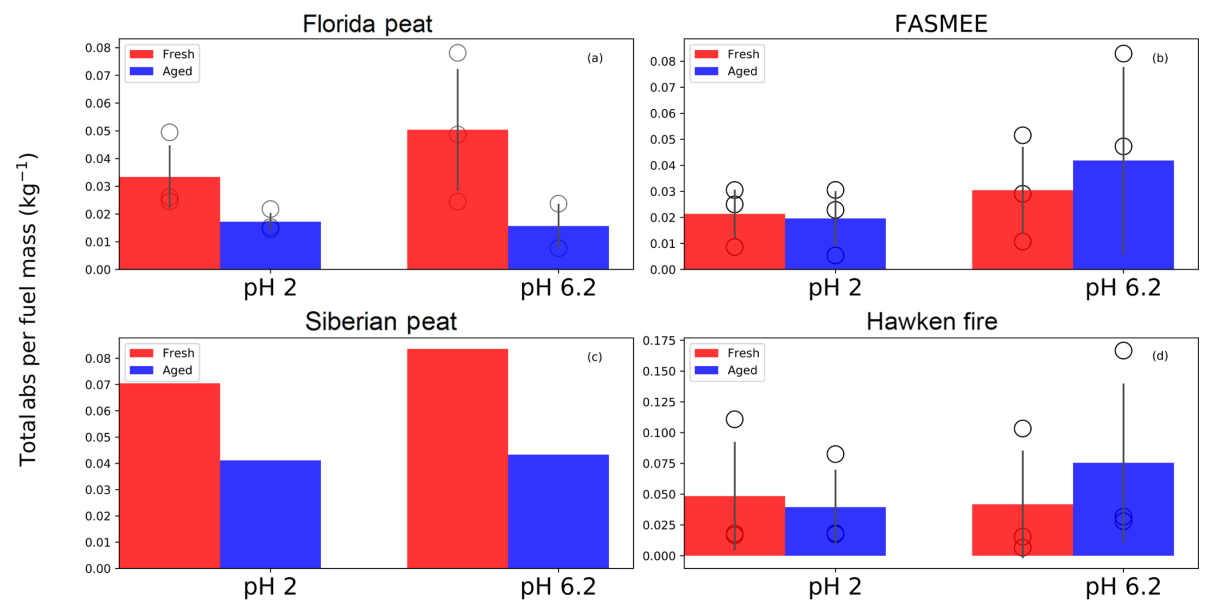

Figure 7. Comparison of total absorbance per fuel mass consumed for the fresh and aged aerosols in water $(\mathrm{pH}=6.2)$ and water extracts $(\mathrm{pH}=2)$, normalized to $1 \mathrm{~mL}$ extraction volumes. Bars, circles, and error bars represent the mean values, individual observations, and standard deviations, respectively. No error bars are given for Siberian peat, because only one experiment was performed with this fuel.

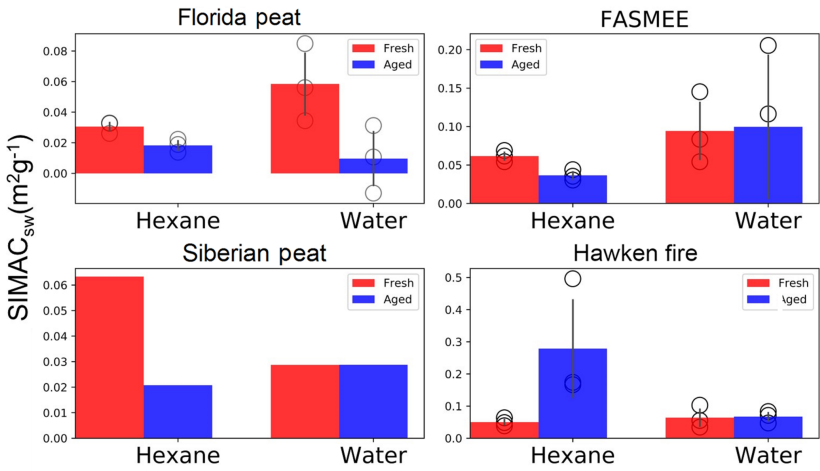

Figure 8. Comparison of the total solar-weighted spectrally integrated mass absorption coefficient $\left(\mathrm{SIMAC}_{\mathrm{sw}}\right.$, units: $\mathrm{m}^{2}$ per gram of OC) for the fresh and aged aerosols in water and hexane extracts, normalized to $1 \mathrm{~mL}$ extraction volumes. Bars, circles, and error bars represent the mean values, individual observations, and standard deviations, respectively. No error bars are given for Siberian peat, because only one experiment was performed with this fuel.

were found for hexane extracts of Hawken fire aged aerosols, whereas the lowest value $\left(\sim 0.02 \mathrm{~m}^{2} \mathrm{~g}^{-1}\right)$ was observed for hexane extracts of aged Florida peat combustion aerosols. For example, the SIMAC $_{\mathrm{sw}}$ of the Florida peat BBOA hexane extracts was reduced from $\sim 0.03$ to $\sim 0.018 \mathrm{~m}^{2} \mathrm{~g}^{-1}$ upon oxidation in the OFR, which is almost a $40 \%$ reduction. This change is statistically significant $(p=0.007)$. An approximately $65 \%$ reduction in the SIMAC $_{\mathrm{sw}}$ of the water extracts upon oxidation was observed for the Florida peat BBOA, but the result has a low statistical significance $(p=0.18)$. Also, the SIMAC $\mathrm{sw}_{\mathrm{sw}}$ values for the hexane extracts of aged Siberian peat BBOA were about 3 times lower than that of fresh BBOA, while for the water extracts, the SIMAC $_{\mathrm{sw}}$ did not change significantly $(<4 \%)$ upon oxidation.
Table 1. Summary of SIMAC $\mathrm{Sw}_{\mathrm{w}}$ and $\mathrm{MAC}_{365}$ (mass absorption coefficient at $365 \mathrm{~nm}$ ) values for water and hexane extracts of $\mathrm{BB}$ emissions from four analyzed fuels.

\begin{tabular}{lcc|cc}
\hline & \multicolumn{2}{c|}{ Water } & \multicolumn{2}{c}{ Hexane } \\
\cline { 2 - 5 } Fuels & $\begin{array}{c}\mathrm{SIMAC}_{\mathrm{SW}} \\
\text { ratio }\end{array}$ & $\begin{array}{c}\mathrm{MAC}_{365} \\
\text { ratio }\end{array}$ & $\begin{array}{c}\mathrm{SIMAC}_{\mathrm{SW}} \\
\text { ratio }\end{array}$ & $\begin{array}{c}\mathrm{MAC}_{365} \\
\text { ratio }\end{array}$ \\
\hline Florida peat & 6.04 & 2.09 & 1.67 & 1.38 \\
FAASME & 0.95 & 1.04 & 1.68 & 1.69 \\
Hawken fire & 0.96 & 0.16 & 0.18 & 0.18 \\
Siberian peat & 1.15 & 0.81 & 3.63 & 3.59 \\
\hline
\end{tabular}

For the fuels with a dominant flaming combustion phase, the SIMAC $_{\mathrm{sw}}$ values of aged BBOA water extracts were higher than those of fresh BBOA water extracts. For example, SIMAC $_{\mathrm{sw}}$ values for the aged FASMEE BBOA water extracts were $\sim 5 \%$ higher than those for the fresh BBOA extracts. This is mostly due to the increase of the absorbance in the $380-550 \mathrm{~nm}$ wavelength range for the aged samples (see Fig. 2), but this increase was not supported by the statistical significance test $(p=0.91)$. For hexane extracts with the same FAASME fuel, Fig. 8 shows that the SIMAC $_{\mathrm{sw}}$ values of aged BBOA particles decreased compared to those of the fresh ones. This change is statistically significant $(p=$ 0.019). TotalAbS values for the FAASME BBOA hexane extracts are also in agreement with the general trend found for SIMAC $_{\text {sw }}$ values (see Fig. 3 ) that decreased $\sim 42 \%$ due to aging.

In summary, we conclude that the light-absorbing $\mathrm{BrC}$ compounds present in SOA derived from open flaming combustion of our samples from alpine or boreal forests have higher light absorption efficiencies (normalized with respect to organic carbon, units: $\mathrm{m}^{2}$ per gram of OC) compared to the compounds emitted from smoldering combustion of peat 
fuels. Most of the previous research has considered $\mathrm{MAC}_{365}$ as a proxy for light-absorbing properties of biomass-burning aerosols (e.g., J. Liu et al., 2013; Zhang et al., 2013). We compared our reported SIMAC $_{\mathrm{sw}}$ values with $\mathrm{MAC}_{365}$ values computed from the same experiments (in Table 1). The fresh/aged ratios of either $\mathrm{SIMAC}_{\mathrm{sw}}$ or $\mathrm{MAC}_{365}$ are supposed to be larger than 1 if the absorbance of BBOA decreases after aging and smaller than 1 when absorbance of BBOA increases upon aging. We observed an underestimation of the $\mathrm{MAC}_{365}$, while predicting a decrease in light absorption upon oxidation (e.g., Florida peat BBOA water extract: fresh/aged ratio with $\mathrm{MAC}_{365}$ is 2.09 where $\mathrm{SIMAC}_{\mathrm{Sw}}$ ratio is 6.04). Also, an overestimation of $\mathrm{MAC}_{365}$ was found for the Hawken fire fuel BBOA, while predicting the increase in light absorption after aging $\left(\mathrm{MAC}_{365}=0.159\right.$ where $\operatorname{SIMAC}_{\mathrm{sw}}=0.956$ for Hawken fire).

\subsection{Change in absorption Ångström exponent (AAE) with aging/oxidation}

The absorption Ångström exponent (AAE) is a key parameter characterizing the spectral dependence of aerosol and bulk (e.g., extracts) light absorption (Moosmüller et al., 2011). BC aerosol from fossil fuel burning typically has AAE values close to 1 , which signifies a wavelength-independent refractive index (Lack et al., 2014). Aerosol AAE values slightly greater than 1 indicate the presence of $\mathrm{BC}$ coatings or of some BrC mixed with BC (Gyawali et al., 2009; Pokhrel et al., 2016). High AAE values have been reported for OC emitted by mostly smoldering combustion. Examples include bulk AAE values of up to $\sim 7$ for HULIS extracts (Hoffer et al., 2006) and aerosol AAE values of up to $\sim 10$ for aerosols from peat combustion (Chakrabarty et al., 2016).

The molecular $\mathrm{O}: \mathrm{C}$ ratio is an important indicator of oxidation in aerosol samples (Aiken et al., 2008). The relative intensity-weighted $\mathrm{O}: \mathrm{C}$ ratios, calculated from the negative ion ultrahigh-resolution mass spectra of SPE-recovered WSOC ranged from 0.27 to 0.33 for the $\mathrm{CHO}$ molecular formulas and 0.20 to 0.48 for the CHNO molecular formulas. The bulk AAE values for the water extracts were calculated (see Sect. 2.5) and are plotted in Fig. 9 as a function of the $\mathrm{O}: \mathrm{C}$ ratios. AAE determined by linear regression from 200 to $400 \mathrm{~nm}\left(\mathrm{AAE}_{(200-400)}\right)$ and from 400 to $600 \mathrm{~nm}$ $\left(\mathrm{AAE}_{(400-600)}\right)$ are shown in Fig. 9a and b and in Fig. 9c and $\mathrm{d}$, respectively, as function of the $\mathrm{O}: \mathrm{C}$ ratios for the $\mathrm{CHO}$ (on left) and the CHNO (on right) molecular formulas. The solid symbols correspond to fresh emissions from combustion of a particular fuel and the void symbols represent the aged samples for the same fuels. For Siberian peat, the size of the symbols increases with the oxidation voltage applied in the OFR reactor.

The $\mathrm{AAE}_{(200-400)}$ values ranged from 4 to 5.5 and increased with oxidation. For all aged emissions, the $\mathrm{AAE}_{(200-400)}$ values were larger than those for fresh emissions, indicating a stronger wavelength dependence of ab- sorption in the $200-400 \mathrm{~nm}$ wavelength range for aged emissions. We observed a similar trend for $\mathrm{AAE}_{(400-600)}$ with a single exception for the emissions from the Hawken fire fuel, where the $\operatorname{AAE}_{(400-600)}$ values decreased after aging. However, the $\mathrm{AAE}_{(400-600)}$ values were much higher (i.e., 7-17) than the $\mathrm{AAE}_{(200-400)}$ values and their changes during aging/oxidation were also more pronounced (e.g., for Florida peat smoke from 6.93 to 15.59). In conclusion, the aging of $\mathrm{BB}$ emissions generally (but not always) increases the AAE values for the water extracts and these $\mathrm{AAE}$ values can be unusually large in the 400 to $600 \mathrm{~nm}$ wavelength range; this is mostly due to the enhanced absorption around $450 \mathrm{~nm}$ as can be seen in Fig. 2. Overall, the aged BBOA from both flaming (e.g., FASMEE fuel) and smoldering (e.g., Florida peat fuels) combustion showed an increase in the peak relative intensity-weighted $\mathrm{O}: \mathrm{C}$ ratios with a larger increase for the flaming combustion experiments (e.g., from 0.33 to 0.47 for Hawken fire fuel). In conclusion, it can be inferred that more oxygenated compounds were found in CHNO molecular formulas from aged samples. This supports our hypothesis regarding organic nitrogen compound formation from the flaming emissions. To investigate the nature of the BBOA, we analyzed the ultrahigh-resolution MS data for our samples. The elemental ratios of $\mathrm{O}: \mathrm{C}$ and $\mathrm{H}: \mathrm{C}$ are used to visualize the molecular nature of BBOA (Van Krevelen, 1950). The elemental ratios do not give exact structural compositions but they provide insight regarding the extent of oxidation and saturation. The comparison of fresh to aged FASMEE fuel aerosol indicates that species uniquely observed in the aged FASMEE fuel are more oxidized than the unique species of the fresh FASMEE fuel (Fig. 10).

Figure 10 shows a loss/transformation of some of the water-soluble organic ions with $\mathrm{O}: \mathrm{C}$ ratio $<0.3$ observed in fresh water-soluble aerosol (colored circles in Fig. 10a) and a formation of mostly more oxidized compounds with $\mathrm{O}: \mathrm{C}>0.25$ (colored circles in Fig. 10b) during the aging of FASMEE aerosol. Several uniquely observed CHO molecular formulas appear to have formed during the oxidation of FASMEE fuel emissions. DBEs are used for the characterization of the degree of unsaturation in a molecular formula and represent the sum of rings and double bonds. Both $\mathrm{CHO}$ and $\mathrm{CHNO}$ molecular formulas formed during the aging process, including a large number of compounds with a high degree of unsaturation (DBE $=10-15)$. The highly unsaturated compounds may contribute to the light absorption of the aged FASMEE aerosol water extract. Aiken et al. (2008) performed high-resolution TOF AMS analysis on aerosols collected from laboratory combustion of lodgepole pine and sagebrush separately. The $\mathrm{O}: \mathrm{C}$ ratios of their laboratory experiments were 0.3 and 0.4 , which are lower than that of ambient samples $(>0.5)$ collected in northern New Mexico during wildfires. Ambient samples were supposedly photochemically aged and thus more oxidized, which was reflected in the increase of the $\mathrm{O}: \mathrm{C}$ ratio. In our study, we observed a similar increase in the oxidation for the OFR-aged water- 

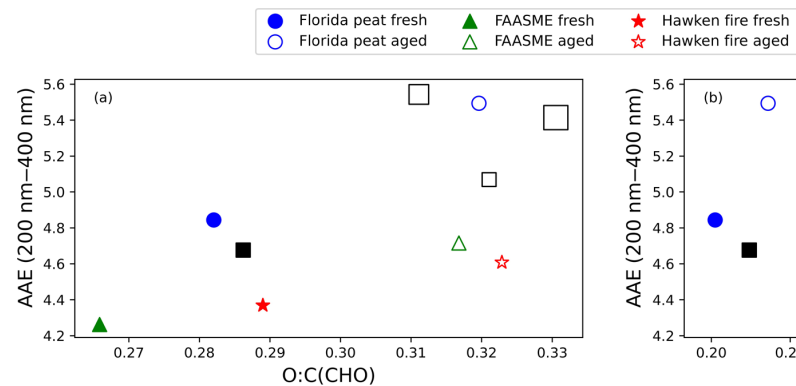

Siberian peat fresh
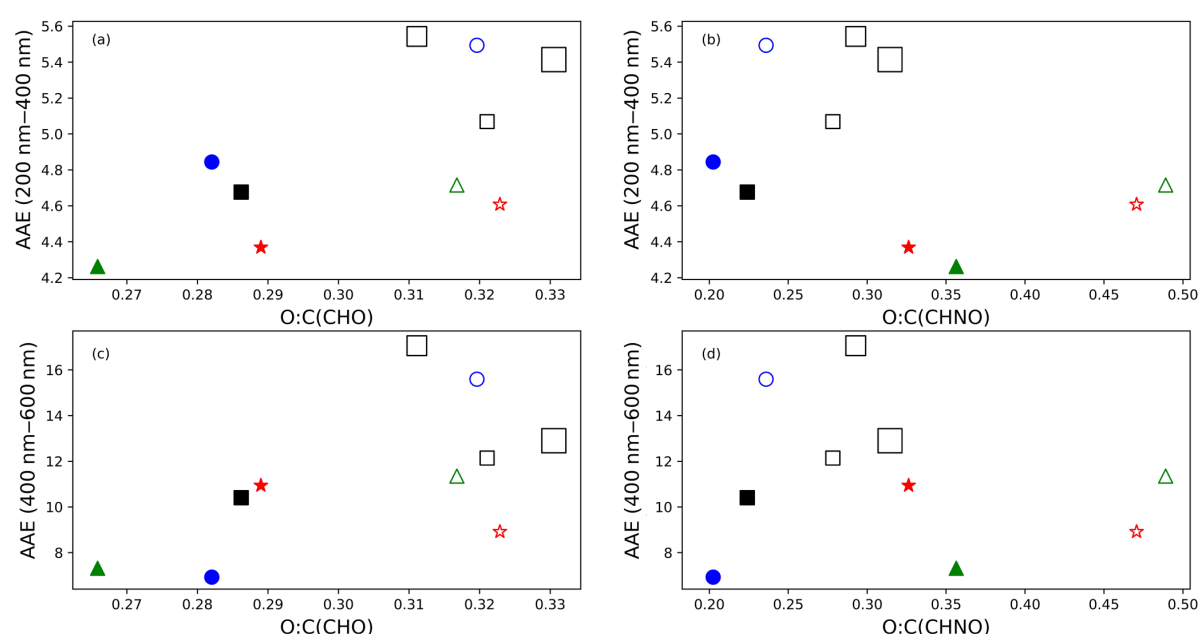

Figure 9. Absorption Ångström exponent (AAE) for the water extracts as a function of oxidation. Solid symbols represent fresh aerosols for a fuel type, and open symbols of the same shape represent the aged aerosols for the same fuel. For Siberian peat, the size of the symbol increases with the oxidation voltage in the OFR reactor.

(a)

\section{Van Krevelen diagrams}

FASMEE fresh

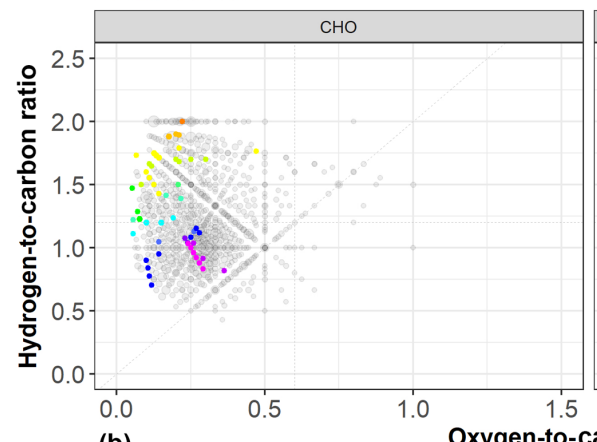

(b)

FASMEE aged

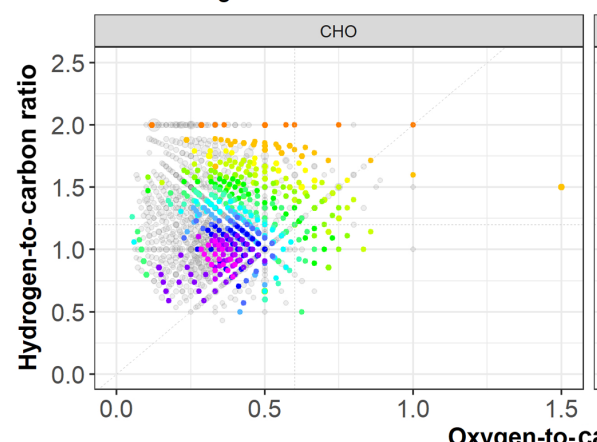

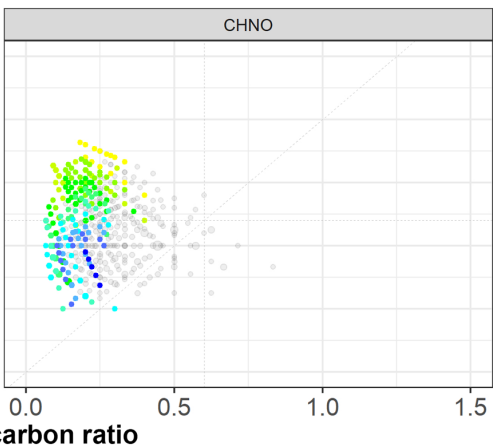

(a)

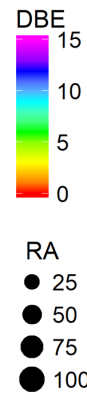

(b)

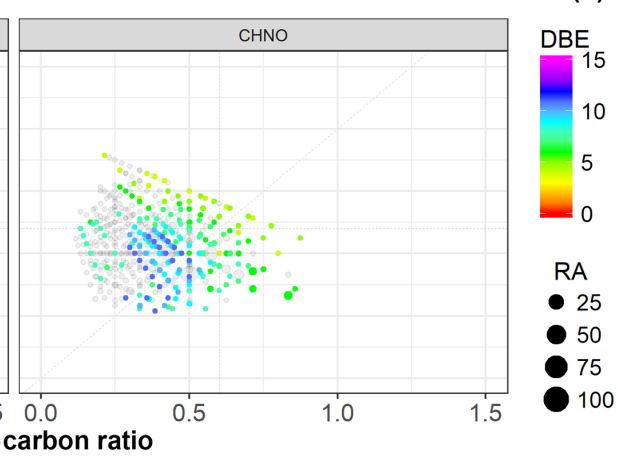

Figure 10. Van Krevelen plots of $\mathrm{H}: \mathrm{C}$ and $\mathrm{O}: \mathrm{C}$ ratios for the negative ion ultrahigh-resolution mass spectra of fresh (a) and aged (b) FASMEE water-soluble aerosol. $\mathrm{CHO}$ and $\mathrm{CHNO}$ molecular formulas are shown separately. Grey circles indicate common molecular formulas observed in both the fresh and aged samples; colored circles indicate the unique molecular formulas for the fresh or aged water-soluble aerosol. The color represents the number of DBEs and the size of the circles indicates the normalized relative abundance of the peaks in the mass spectra. 


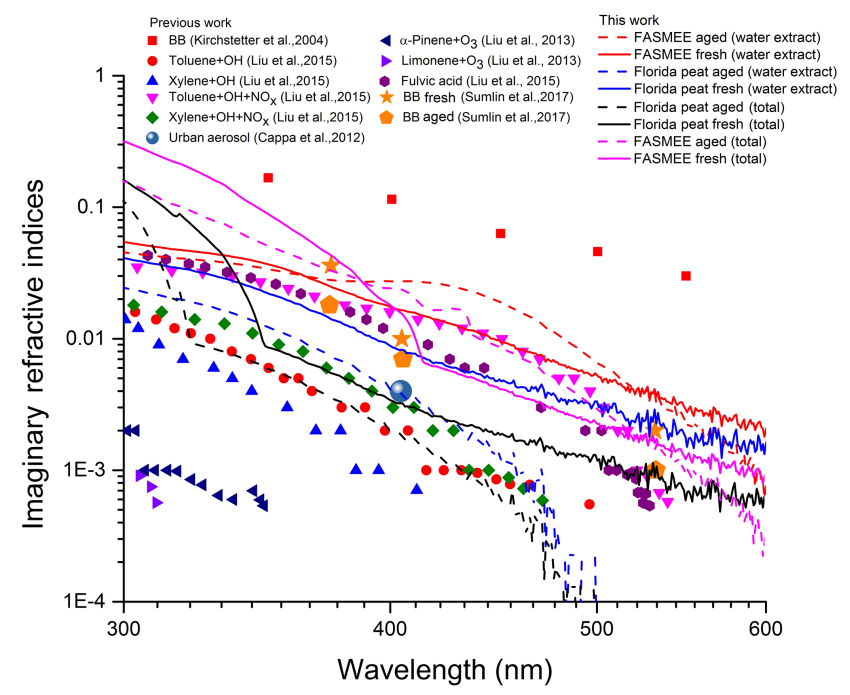

Figure 11. Comparison of the imaginary part of the bulk refractive indices from previous work with water extracts and total (hexane + water) extracts of the fresh BBOA (solid lines) and aged BBOA (dotted lines) as a function of wavelength.

soluble aerosol collected from combustion experiments of the FASMEE fuel.

\subsection{Imaginary part of the bulk refractive index of water extracts}

Figure 11 shows a comparison of the bulk imaginary refractive indices retrieved for water extracts and the total (hexane + water) extract of BBOA measured in this study with the imaginary refractive indices reported in the literature. The previously reported data include those from early work by Kirchstetter et al. (2004) on BB aerosols, biogenic SOA (P. Liu et al., 2013), anthropogenic SOA (Liu et al., 2015) generated from laboratory precursor oxidation experiments, urban BrC (Cappa et al., 2013), and Mie theory retrieved imaginary refractive indices from a similar campaign conducted at Washington University in St. Louis (Sumlin et al., 2017). The imaginary part of the bulk refractive indices was retrieved separately for water (Fig. S5) and hexane extracts (Fig. S6) and then simple mass mixing rules were used to compute the total contribution (Eq. 11a, b, c). In Fig. 11, the bulk refractive indices for both the water and the total were plotted for comparison. Bulk refractive indices for all fuels (both fresh and aged) are higher at shorter wavelengths and decrease gradually toward longer wavelengths, which is typical for $\mathrm{BrC}$ aerosols. The total bulk imaginary refractive indices were higher than those of the water extract only at shorter wavelengths, because the hexane (non-polar) fraction absorbs mostly in the blue and the near-UV part of the spectrum. For fuels that undergo smoldering combustion (e.g., Florida peat), the bulk imaginary refractive indices were smaller for aged BBOA compared to fresh BBOA. On the contrary, emissions from flaming fuel, FASMEE, have very different properties, with the imaginary refractive index of the aged BBOA being smaller than that of fresh BBOA below $400 \mathrm{~nm}$ and above $550 \mathrm{~nm}$, while between 400 and $550 \mathrm{~nm}$ the imaginary refractive index of aged BBOA was higher than that of the fresh BBOA as indicated by the obvious "hump" in Fig. 11. An enhancement of the imaginary refractive indices was also observed by Liu et al. (2015) when an anthropogenic precursor was oxidized in the presence of $\mathrm{NO}_{x}$ to generate SOA. This is consistent with our hypothesis regarding the role of $\mathrm{NO}_{x}$ in the absorption enhancement for flaming fuels.

\section{Summary and conclusions}

In this study, we analyzed the absorption properties of biomass-burning aerosols from four different globally and regionally important fuels that represent both smoldering and flaming combustion processes. Our goal was to understand how the light-absorbing properties of these combustion experiments was affected by aging (OFR aging) and what compounds (polar or non-polar) contribute to the light absorption of BB aerosols. We found that the non-polar fraction absorbs more than the polar fraction. However, most of the light absorption by the non-polar fraction was attributed to UV and the shorter part of the visible wavelength range. Light absorption by the HULIS fraction was also compared with the light absorption properties of the total water extracts and we found that for the Hawken fire fuel emissions, the light-absorbing compounds were most likely high molecular weight organic species. As the $\mathrm{pH}$ of the freshly emitted BBOA can decrease due to atmospheric processing and mixing with more acidic inorganic aerosols, we also compared the light absorption properties of acidified and non-acidified water extracts. We found that the TotalAbs decreased with the decrease in $\mathrm{pH}$, which can be explained by potential protonation of functional groups at lower $\mathrm{pH}(\mathrm{pH}=2)$. Lightabsorbing properties do change upon aging/oxidation, and we were able to distinguish the change in the light absorption characteristics of flaming and smoldering combustion emissions. For flaming fuel combustion samples, the absorbance values decreased for non-polar hexane extracts upon oxidation/aging, but in the case of the polar extracts an increase in the absorbance values was observed, especially in the $450-500 \mathrm{~nm}$ wavelength range. We also observed significantly higher $\mathrm{NO}_{x}$ levels during flaming fuel combustion (e.g., $\left[\mathrm{NO}_{x}\right]_{\max }=2068 \mathrm{ppb}$ ) compared to smoldering combustion (e.g., $\left[\mathrm{NO}_{x}\right]_{\max }=88 \mathrm{ppb}$ for Florida peat). Results from the ultrahigh-resolution mass spectrometry analysis showed unique organic nitrogen species that likely formed during aerosol aging/oxidation in the presence of $\mathrm{NO}_{x}$. However, the reason behind this high $\mathrm{NO}_{x}$ emission is still unknown and whether $\mathrm{NO}_{x}$ emission is related to the fuel ni- 
trogen content or to burning conditions is a matter of future investigation.

Data availability. Data can be provided upon request: andrey.khlystov@dri.edu.

Supplement. The supplement related to this article is available online at: https://doi.org/10.5194/acp-18-10849-2018-supplement.

Author contributions. DS, VS, CB, and AK designed experiments. DS, CB, and MIL performed data collection. DS performed spectrophotometry measurements, summarized data, and wrote the paper. EK and LM performed ultra-high-resolution mass spectrometry analyses. AK, VS, HM, EK, and LM provided input on interpretation of results. AW provided biomass fuels. VS, AK, and HM revised the manuscript.

Competing interests. The authors declare that they have no conflict of interest.

Acknowledgements. This research was supported by the National Science Foundation (NSF) under grant nos. AGS-1544425 and AGS-1408241, NASA ROSES under grant no. NNX15AI48G, and internal funding from the Desert Research Institute. The authors would like to thank Anna Tsibar (Moscow State Lomonosov University, Moscow, Russia) for providing Siberian peat fuel, Anna Cunningham (DRI) for technical assistance with extraction procedure, and Lan Gao (DRI) for assisting in data analysis.

Edited by: Alexander Laskin

Reviewed by: four anonymous referees

\section{References}

Aiken, A. C., DeCarlo, P. F., Kroll, J. H., Worsnop, D. R., Huffman, J. A., Docherty, K. S., Ulbrich, I. M., Mohr, C., Kimmel, J. R., Sueper, D., Sun, Y., Zhang, Q., Trimborn, A., Northway, M., Ziemann, P. J., Canagaratna, M. R., Onasch, T. B., Alfarra, M. R., Prevot, A. S. H., Dommen, J., Duplissy, J., Metzger, A., Baltensperger, U., and Jimenez, J. L.: O/C and OM/OC Ratios of Primary, Secondary, and Ambient Organic Aerosols with High-Resolution Time-of-Flight Aerosol Mass Spectrometry, Environ. Sci. Technol., 42, 4478-4485, https://doi.org/10.1021/es703009q, 2008.

Akagi, S. K., Yokelson, R. J., Wiedinmyer, C., Alvarado, M. J., Reid, J. S., Karl, T., Crounse, J. D., and Wennberg, P. O.: Emission factors for open and domestic biomass burning for use in atmospheric models, Atmos. Chem. Phys., 11, 4039-4072, https://doi.org/10.5194/acp-11-4039-2011, 2011.

Andreae, M. O.: Atmospheric Aerosols: Biogeochemical Sources and Role in Atmospheric Chemistry, Science, 276, 1052-1058, https://doi.org/10.1126/science.276.5315.1052, 1997.
Andreae, M. O. and Gelencsér, A.: Black carbon or brown carbon? The nature of light-absorbing carbonaceous aerosols, Atmos. Chem. Phys., 6, 3131-3148, https://doi.org/10.5194/acp-63131-2006, 2006.

Arbex, M. A., Martins, L. C., Carvalho De Oliveira, R., Pereira, A. A., Arbex, F. F., Eduardo, J., Cançado, D., Hilário, P., Saldiva, N., Luís, A., and Braga, F.: Air pollution from biomass burning and asthma hospital admissions in a sugar cane plantation area in Brazil, J. Epidemiol. Community Heal., 61, 395-400, https://doi.org/10.1136/jech.2005.044743, 2007.

Baes, A. U. and Bloom, P. R.: Fulvic Acid Ultraviolet-Visible Spectra: Influence of Solvent and pH, Soil Sci. Soc. Am. J., 54, 1248-1254, https://doi.org/10.2136/sssaj1990.03615995005400050008x, 1990.

Bhattarai, C., Samburova, V., Sengupta, D., Iaukea-Lum, M., Watts, A. C., Moosmüller, H., and Khlystov, A.: Physical and chemical characterization of fresh and aged emissions from open combustion of biomass fuels, Aerosol Sci. Technol., accepted, https://doi.org/10.1080/02786826.2018.1498585, 2018.

Bond, T. C. and Bergstrom, R. W.: Light Absorption by Carbonaceous Particles: An Investigative Review, Aerosol Sci. Technol., 40, 27-67, https://doi.org/10.1080/02786820500421521, 2006.

Bougiatioti, A., Nikolaou, P., Stavroulas, I., Kouvarakis, G., Weber, R., Nenes, A., Kanakidou, M., and Mihalopoulos, N.: Particle water and $\mathrm{pH}$ in the eastern Mediterranean: Source variability and implications for nutrient availability, Atmos. Chem. Phys., 16, 4579-4591, https://doi.org/10.5194/acp-164579-2016, 2016.

Brown, D. R. N., Jorgenson, M. T., Douglas, T. A., Romanovsky, V. E., Kielland, K., Hiemstra, C., Euskirchen, E. S., and Ruess, R. W.: Interactive effects of wildfire and climate on permafrost degradation in Alaskan lowland forests, J. Geophys. Res.-Biogeosci., 120, 1619-1637, https://doi.org/10.1002/2015JG003033, 2015.

Cappa, C. D., Onasch, T. B., Massoli, P., Worsnop, D. R., Bates, T. S., Cross, E. S., Davidovits, P., Hakala, J., Hayden, K. L., Jobson, B. T., Kolesar, K. R., Lack, D. A., Lerner, B. M., Li, S.-M., Mellon, D., Nuaaman, I., Olfert, J. S., Petaja, T., Quinn, P. K., Song, C., Subramanian, R., Williams, E. J., and Zaveri, R. A.: Radiative Absorption Enhancements Due to the Mixing State of Atmospheric Black Carbon, Science, 337, 1078-1081, https://doi.org/10.1126/science.1223447, 2012.

Cappa, C. D., Onasch, T. B., Massoli, P., Worsnop, D. R., Bates, T. S., Cross, E. S., Davidovits, P., Hakala, J., Hayden, K. L., Jobson, B. T., Kolesar, K. R., Lack, D. A., Lerner, B. M., Li, S.-M., Mellon, D., Quinn, P. K., Song, C., Subramanian, R., Williams, E. J., and Zaveri, R. A.: Response to Comment on "Radiative Absorption Enhancements Due to the Mixing State of Atmospheric Black Carbon", Science, 393, 1078-1082, https://doi.org/10.1126/science.1230260, 2013.

Chakrabarty, R. K., Gyawali, M., Yatavelli, R. L. N., Pandey, A., Watts, A. C., Knue, J., Chen, L.-W. A., Pattison, R. R., Tsibart, A., Samburova, V., and Moosmüller, H.: Brown carbon aerosols from burning of boreal peatlands: microphysical properties, emission factors, and implications for direct radiative forcing, Atmos. Chem. Phys., 16, 3033-3040, https://doi.org/10.5194/acp-16-3033-2016, 2016. 
Chen, Y. and Bond, T. C.: Light absorption by organic carbon from wood combustion, Atmos. Chem. Phys., 10, 1773-1787, https://doi.org/10.5194/acp-10-1773-2010, 2010.

China, S., Mazzoleni, C., Gorkowski, K., Aiken, A. C., and Dubey, M. K.: Morphology and mixing state of individual freshly emitted wildfire carbonaceous particles., Nat. Commun., 4, 2122, https://doi.org/10.1038/ncomms3122, 2013.

Chow, J. C., Watson, J. G., Pritchett, L. C., Pierson, W. R., Frazier, C. A., and Purcell, R. G.: The DRI thermal optical reflectance carbon analysis system - description, evaluation and applications in United-States air quality studies, Atmos. Environ. A, 27, 1185-1201, 1993.

Chow, J. C., Watson, J. G., Chen, L. W. A., Arnott, W. P., Moosmüller, H., and Fung, K.: Equivalence of elemental carbon by thermal/optical reflectance and transmittance with different temperature protocols, Environ. Sci. Technol., 38, 4414-4422, https://doi.org/10.1021/es034936u, 2004.

Corr, C. A., Hall, S. R., Ullmann, K., Anderson, B. E., Beyersdorf, A. J., Thornhill, K. L., Cubison, M. J., Jimenez, J. L., Wisthaler, A., and Dibb, J. E.: Spectral absorption of biomass burning aerosol determined from retrieved single scattering albedo during ARCTAS, Atmos. Chem. Phys., 12, 10505-10518, https://doi.org/10.5194/acp-12-10505-2012, 2012.

Dinar, E., Mentel, T. F., and Rudich, Y.: The density of humic acids and humic like substances (HULIS) from fresh and aged wood burning and pollution aerosol particles, Atmos. Chem. Phys., 6, 5213-5224, https://doi.org/10.5194/acp-6-5213-2006, 2006.

Drinovec, L., Močnik, G., Zotter, P., Prévôt, A. S. H., Ruckstuhl, C., Coz, E., Rupakheti, M., Sciare, J., Müller, T., Wiedensohler, A., and Hansen, A. D. A.: The "dual-spot" Aethalometer: An improved measurement of aerosol black carbon with realtime loading compensation, Atmos. Meas. Tech., 8, 1965-1979, https://doi.org/10.5194/amt-8-1965-2015, 2015.

Drinovec, L., Gregoric, A., Zotter, P., Wolf, R., Anne Bruns, E., Bruns, E. A., Prevot, A. S. H., Favez, O., Sciare, J., Arnold, I. J., Chakrabarty, R. K., Moosmüller, H., Filep, A., and Mocnik, G.: The filter-loading effect by ambient aerosols in filter absorption photometers depends on the coating of the sampled particles, Atmos. Meas. Tech., 10, 1043-1059, https://doi.org/10.5194/amt10-1043-2017, 2017.

Finlayson-Pitts, B. J. and Pitts Jr., J. N.: Chemistry of the upper and lower atmosphere: theory, experiments and applications, San Diego, CA, Academic Press, 1999.

Formenti, P.: Inorganic and carbonaceous aerosols during the Southern African Regional Science Initiative (SAFARI 2000) experiment: Chemical characteristics, physical properties, and emission data for smoke from African biomass burning, J. Geophys. Res., 108, 1-16, https://doi.org/10.1029/2002JD002408, 2003.

Graber, E. R. and Rudich, Y.: Atmospheric HULIS: How humiclike are they? A comprehensive and critical review, Atmos. Chem. Phys., 6, 729-753, https://doi.org/10.5194/acp-6-7292006, 2006.

Gueymard, C. A.SMARTS2: a simple model of the atmospheric radiative transfer of sunshine: algorithms and performance assessment, Report No. FSEC-PF-270-9, 1-84, available at: http: //instesre.org/GCCE/SMARTS2.pdf (last access: 25 July 2018), 1995.

Gyawali, M., Arnott, W. P., Lewis, K., and Moosmüller, H.: In situ aerosol optics in Reno, NV, USA during and after the summer
2008 California wildfires and the influence of absorbing and nonabsorbing organic coatings on spectral light absorption, Atmos. Chem. Phys., 9, 8007-8015, https://doi.org/10.5194/acp-9-80072009, 2009.

Gyawali, M., Arnott, P. W., Zaveri, A. R., Song, C., Flowers, B., Dubey, K. M., Setyan, A., Zhang, Q., China, S., Mazzoleni, C., Gorkowski, K., Subramanian, R., and Moosmüller, H.: Evolution of Multispectral Aerosol Absorption Properties in a Biogenically-Influenced Urban Environment during the CARES Campaign, Atmosphere, 8, 217, https://doi.org/10.3390/atmos8110217, 2017.

Gysel, M., Weingartner, E., Nyeki, S., Paulsen, D., Baltensperger, U., Galambos, I., and Kiss, G.: Hygroscopic properties of water-soluble matter and humic-like organics in atmospheric fine aerosol, Atmos. Chem. Phys., 4, 35-50, https://doi.org/10.5194/acp-4-35-2004, 2004.

Hecobian, A., Zhang, X., Zheng, M., Frank, N., Edgerton, E. S., and Weber, R. J.: Water-soluble organic aerosol material and the light-absorption characteristics of aqueous extracts measured over the Southeastern United States, Atmos. Chem. Phys., 10, 5965-5977, https://doi.org/10.5194/acp-10-5965-2010, 2010.

Henze, D. K., Seinfeld, J. H., Ng, N. L., Kroll, J. H., Fu, T.-M., Jacob, D. J., and Heald, C. L.: Global modeling of secondary organic aerosol formation from aromatic hydrocarbons: highvs. low-yield pathways, Atmos. Chem. Phys., 8, 2405-2420, https://doi.org/10.5194/acp-8-2405-2008, 2008.

Hobbs, P. V, Reid, J. S., Kotchenruther, R. A., Ferek, R. J., and Weiss, R.: Direct radiative forcing by smoke from biomass burning, Science, 275, 1776-1778, https://doi.org/10.1126/science.275.5307.1777, 1997.

Hoffer, A., Gelencsér, A., Guyon, P., Kiss, G., Schmid, O., Frank, G. P., Artaxo, P., and Andreae, M. O.: Optical properties of humiclike substances (HULIS) in biomass-burning aerosols, Atmos. Chem. Phys., 6, 3563-3570, https://doi.org/10.5194/acp-6-35632006, 2006.

Holben, B. N., Eck, T. F., Slutsker, I., Tanré, D., Buis, J. P., Setzer, A., Vermote, E., Reagan, J. A., Kaufman, Y. J., Nakajima, T., Lavenu, F., Jankowiak, I., and Smirnov, A.: AERONET - A federated instrument network and data archive for aerosol characterization, Remote Sens. Environ., 66, 1-16, https://doi.org/10.1016/S0034-4257(98)00031-5, 1998.

Iinuma, Y., Böge, O., and Herrmann, H.: Methyl-nitrocatechols: Atmospheric tracer compounds for biomass burning secondary organic aerosols, Environ. Sci. Technol., 44, 8453-8459, https://doi.org/10.1021/es102938a, 2010.

Jacobson, M. Z.: The short-term cooling but longterm global warming due to biomass burning, J. Climate, 17, 2909-2926, https://doi.org/10.1175/15200442(2004)017<2909:TSCBLG>2.0.CO;2, 2004.

Jaffe, D. A. and Wigder, N. L.: Ozone production from wildfires: A critical review, Atmos. Environ., 51, 1-10, https://doi.org/10.1016/j.atmosenv.2011.11.063, 2012.

Kahnt, A., Behrouzi, S., Vermeylen, R., Safi Shalamzari, M., Vercauteren, J., Roekens, E., Claeys, M., and Maenhaut, W.: One-year study of nitro-organic compounds and their relation to wood burning in PM10 aerosol from a rural site in Belgium, Atmos. Environ., 81, 561-568, https://doi.org/10.1016/j.atmosenv.2013.09.041, 2013. 
Kirchstetter, T. W., Novakov, T., and Hobbs, P. V.: Evidence that the spectral dependence of light absorption by aerosols is affected by organic carbon, J. Geophys. Res.-Atmos., 109, 1-12, https://doi.org/10.1029/2004JD004999, 2004.

Kiss, G., Varga, B., Galambos, I., and Ganszky, I.: Characterization of water-soluble organic matter isolated from atmospheric fine aerosol, J. Geophys. Res., 107, 8339, https://doi.org/10.1029/2001JD000603, 2002.

Kitanovski, Z., Grgić, I., Yasmeen, F., Claeys, M., and Čusak, A.: Development of a liquid chromatographic method based on ultraviolet-visible and electrospray ionization mass spectrometric detection for the identification of nitrocatechols and related tracers in biomass burning atmospheric organic aerosol, Rapid Commun. Mass Spectrom., 26, 793-804, https://doi.org/10.1002/rcm.6170, 2012.

Kleindienst, T. E., Conver, T. S., McIver, C. D., and Edney, E. O.: Determination of secondary organic aerosol products from the photooxidation of toluene and their implications in ambient $\mathrm{PM}_{2.5}$, J. Atmos. Chem., 47, 79-100, https://doi.org/10.1023/B:JOCH.0000012305.94498.28, 2004.

Koch, D., Schulz, M., Kinne, S., McNaughton, C., Spackman, J. R., Balkanski, Y., Bauer, S., Berntsen, T., Bond, T. C., Boucher, O., Chin, M., Clarke, A., De Luca, N., Dentener, F., Diehl, T., Dubovik, O., Easter, R., Fahey, D. W., Feichter, J., Fillmore, D., Freitag, S., Ghan, S., Ginoux, P., Gong, S., Horowitz, L., Iversen, T., Kirkevåg, A., Klimont, Z., Kondo, Y., Krol, M., Liu, X., Miller, R., Montanaro, V., Moteki, N., Myhre, G., Penner, J. E., Perlwitz, J., Pitari, G., Reddy, S., Sahu, L., Sakamoto, H., Schuster, G., Schwarz, J. P., Seland, Ø., Stier, P., Takegawa, N., Takemura, T., Textor, C., van Aardenne, J. A., and Zhao, Y.: Evaluation of black carbon estimations in global aerosol models, Atmos. Chem. Phys., 9, 9001-9026, https://doi.org/10.5194/acp-99001-2009, 2009.

Lack, D. A. and Cappa, C. D.: Impact of brown and clear carbon on light absorption enhancement, single scatter albedo and absorption wavelength dependence of black carbon, Atmos. Chem. Phys., 10, 4207-4220, https://doi.org/10.5194/acp10-4207-2010, 2010.

Lack, D. A., Moosmüller, H., McMeeking, G. R., Chakrabarty, R. K., and Baumgardner, D.: Characterizing elemental, equivalent black, and refractory black carbon aerosol particles: A review of techniques, their limitations and uncertainties, Anal. Bioanal. Chem., 406, 99-122, https://doi.org/10.1007/s00216-013-74023, 2014.

Laskin, A., Smith, J. S., and Laskin, J.: Molecular Characterization of Nitrogen-Containing Organic Compounds in Biomass Burning Aerosols Using High-Resolution Mass Spectrometry, Environ. Sci. Technol., 43, 3764-3771, https://doi.org/10.1021/es803456n, 2009.

Lee, S. Y., Gan, C., and Chew, B. N.: Visibility deterioration and hygroscopic growth of biomass burning aerosols over a tropical coastal city: A case study over Singapore's airport, Atmos. Sci. Lett., 629, 624-629, https://doi.org/10.1002/asl.712, 2016.

Lewis, K., Arnott, W. P., Moosmüller, H., and Wold, C. E.: Strong spectral variation of biomass smoke light absorption and single scattering albedo observed with a novel dual-wavelength photoacoustic instrument, J. Geophys. Res.-Atmos., 113, 1-14, https://doi.org/10.1029/2007JD009699, 2008.
Li, R., Palm, B. B., Ortega, A. M., Hlywiak, J., Hu, W., Peng, Z., Day, D. A., Knote, C., Brune, W. H., de Gouw, J. A., and Jimenez, J. L.: Modeling the Radical Chemistry in an Oxidation Flow Reactor: Radical Formation and Recycling, Sensitivities, and the $\mathrm{OH}$ Exposure Estimation Equation., J. Phys. Chem. A, 119, 4418-4432, https://doi.org/10.1021/jp509534k, 2015.

Lin, P., Engling, G., and Yu, J. Z.: Humic-like substances in fresh emissions of rice straw burning and in ambient aerosols in the Pearl River Delta Region, China, Atmos. Chem. Phys., 10, 64876500, https://doi.org/10.5194/acp-10-6487-2010, 2010.

Lin, P., Liu, J., Shilling, J. E., Kathmann, S. M., Laskin, J., and Laskin, A.: Molecular characterization of brown carbon $(\mathrm{BrC})$ chromophores in secondary organic aerosol generated from photo-oxidation of toluene, Phys. Chem. Chem. Phys., 17, 23312-23325, https://doi.org/10.1039/C5CP02563J, 2015.

Lin, P., Bluvshtein, N., Rudich, Y., Nizkorodov, S. A., Laskin, J., and Laskin, A.: Molecular Chemistry of Atmospheric Brown Carbon Inferred from a Nationwide Biomass Burning Event, Environ. Sci. Technol., 51, 11561-11570, https://doi.org/10.1021/acs.est.7b02276, 2017.

Liu, C., Chung, C. E., Zhang, F., and Yin, Y.: The colors of biomass burning aerosols in the atmosphere, Sci. Rep., 6, 28267, https://doi.org/10.1038/srep28267, 2016.

Liu, J., Bergin, M., Guo, H., King, L., Kotra, N., Edgerton, E., and Weber, R. J.: Size-resolved measurements of brown carbon in water and methanol extracts and estimates of their contribution to ambient fine-particle light absorption, Atmos. Chem. Phys., 13, 12389-12404, https://doi.org/10.5194/acp-13-123892013, 2013.

Liu, J., Lin, P., Laskin, A., Laskin, J., Kathmann, S. M., Wise, M., Caylor, R., Imholt, F., Selimovic, V., and Shilling, J. E.: Optical properties and aging of light-absorbing secondary organic aerosol, Atmos. Chem. Phys., 16, 12815-12827, https://doi.org/10.5194/acp-16-12815-2016, 2016.

Liu, P., Zhang, Y., and Martin, S. T.: Complex refractive indices of thin films of secondary organic materials by spectroscopic ellipsometry from 220 to $1200 \mathrm{~nm}$, Environ. Sci. Technol., 47, 13594-13601, https://doi.org/10.1021/es403411e, 2013.

Liu, P. F., Abdelmalki, N., Hung, H. M., Wang, Y., Brune, W. H., and Martin, S. T.: Ultraviolet and visible complex refractive indices of secondary organic material produced by photooxidation of the aromatic compounds toluene and m-xylene, Atmos. Chem. Phys., 15, 1435-1446, https://doi.org/10.5194/acp15-1435-2015, 2015.

Liu, Y., Goodrick, S., Achtemeier, G., Jackson, W. A., Qu, J. J., and Wang, W.: Smoke incursions into urban areas: Simulation of a Georgia prescribed burn, Int. J. Wildl. Fire, 18, 336-348, https://doi.org/10.1071/WF08082, 2009.

Lowenthal, D., Zielinska, B., Mason, B., Samy, S., Samburova, V., Collins, D., Spencer, C., Taylor, N., Allen, J., and Kumar, N.: Aerosol characterization studies at Great Smoky Mountains National Park, summer 2006, J. Geophys. Res., 114, D08206, https://doi.org/10.1029/2008JD011274, 2009.

Mayol-Bracero, O. L., Guyon, P., Graham, B., Roberts, G., Andreae, M. O., Decesari, S., Facchini, M. C., Fuzzi, S., and Artaxo, P.: Water-soluble organic compounds in biomass burning aerosols over Amazonia Apportionment of the chemical composition and importance of the poly- 
acidic fraction, J. Geophys. Res.-Atmos., 107, 591-5915, https://doi.org/10.1029/2001JD000522, 2002.

Mazzoleni, L. R., Ehrmann, B. M., Shen, X., Marshall, A. G., and Collett, J. L.: Water-Soluble Atmospheric Organic Matter in Fog: Exact Masses and Chemical Formula Identification by Ultrahigh-Resolution Fourier Transform Ion Cyclotron Resonance Mass Spectrometry, Environ. Sci. Technol., 44, 36903697, https://doi.org/10.1021/es903409k, 2010.

Moosmüller, H., Chakrabarty, R. K., and Arnott, W. P.: Aerosol light absorption and its measurement: A review, J. Quant. Spectrosc. Radiat. Transf., 110, 844-878, https://doi.org/10.1016/j.jqsrt.2009.02.035, 2009.

Moosmüller, H., Chakrabarty, R. K., Ehlers, K. M., and Arnott, W. P.: Absorption Ångström coefficient, brown carbon, and aerosols: Basic concepts, bulk matter, and spherical particles, Atmos. Chem. Phys., 11, 1217-1225, https://doi.org/10.5194/acp11-1217-2011, 2011.

Ng, N. L., Chhabra, P. S., Chan, A. W. H., Surratt, J. D., Kroll, J. H., Kwan, A. J., McCabe, D. C., Wennberg, P. O., Sorooshian, A., Murphy, S. M., Dalleska, N. F., Flagan, R. C., and Seinfeld, J. H.: Effect of NOx level on secondary organic aerosol (SOA) formation from the photooxidation of terpenes, Atmos. Chem. Phys., 7, 5159-5174, https://doi.org/10.5194/acp-7-5159-2007, 2007a.

Ng, N. L., Kroll, J. H., Chan, A. W. H., Chhabra, P. S., Flagan, R. C., and Seinfeld, J. H.: Secondary organic aerosol formation from m-xylene, toluene, and benzene, Atmos. Chem. Phys., 7, 3909-3922, https://doi.org/10.5194/acp-7-3909-2007, 2007b.

Ng, N. L., Kwan, A. J., Surratt, J. D., Chan, A. W. H., Chhabra, P. S., Sorooshian, A., Pye, H. O. T., Crounse, J. D., Wennberg, P. O., Flagan, R. C., and Seinfeld, J. H.: Secondary organic aerosol (SOA) formation from reaction of isoprene with nitrate radicals $\left(\mathrm{NO}_{3}\right)$, Atmos. Chem. Phys., 8, 4117-4140, https://doi.org/10.5194/acp-8-4117-2008, 2008.

Park, R. J., Jacob, D. J., and Logan, J. A.: Fire and biofuel contributions to annual mean aerosol mass concentrations in the United States, Atmos. Environ., 41, 7389-7400, https://doi.org/10.1016/j.atmosenv.2007.05.061, 2007.

Phillips, S. M., Bellcross, A. D., and Smith, G. D.: Light Absorption by Brown Carbon in the Southeastern United States is pH-dependent, Environ. Sci. Technol., 51, 6782-6790, https://doi.org/10.1021/acs.est.7b01116, 2017.

Podgorny, I. A., Li, F., and Ramanathan, V.: Large Aerosol Radiative Forcing due to the 1997 Indonesian Forest Fire, Geophys. Res. Lett., 30, 1028, https://doi.org/10.1029/2002GL015979, 2003.

Pokhrel, R. P., Wagner, N. L., Langridge, J. M., Lack, D. A., Jayarathne, T., Stone, E. A., Stockwell, C. E., Yokelson, R. J. and Murphy, S. M.: Parameterization of single-scattering albedo (SSA) and absorption Ångström exponent (AAE) with EC/OC for aerosol emissions from biomass burning, Atmos. Chem. Phys., 16, 9549-9561, https://doi.org/10.5194/acp-169549-2016, 2016.

Putman, A. L., Offenberg, J. H., Fisseha, R., Kundu, S., Rahn, T. A., and Mazzoleni, L. R.: Ultrahighresolution FT-ICR mass spectrometry characterization of $\alpha$-pinene ozonolysis SOA, Atmos. Environ., 46, 164-172, https://doi.org/10.1016/j.atmosenv.2011.10.003, 2012.
Ramanathan, V., Crutzen, P. J., Kiehl, J. T., and Rosenfeld, D.: Atmosphere - Aerosols, Climate, and the Hydrological Cycle, Science, 294, 2119-2124, 2001.

Reddy, K. R. and DeLaune, R. D.: Biogeochemistry of WETLANDS, CRC Press, London, 2008.

Regalado, J., Pérez-Padilla, R., Sansores, R., Ramirez, J. I. P., Brauer, M., Paré, P., and Vedal, S.: The effect of biomass burning on respiratory symptoms and lung function in rural Mexican women, Am. J. Respir. Crit. Care Med., 174, 901-905, https://doi.org/10.1164/rccm.200503-479OC, 2006.

Samburova, V., Szidat, S., Hueglin, C., Fisseha, R., Baltensperger, U., Zenobi, R., and Kalberer, M.: Seasonal variation of highmolecular-weight compounds in the water-soluble fraction of organic urban aerosols, J. Geophys. Res., 110, D23210, https://doi.org/10.1029/2005JD005910, 2005.

Samburova, V., Connolly, J., Gyawali, M., Yatavelli, R. L. N., Watts, A. C., Chakrabarty, R. K., Zielinska, B., Moosmüller, H., and Khlystov, A.: Polycyclic aromatic hydrocarbons in biomass-burning emissions and their contribution to light absorption and aerosol toxicity, Sci. Total Environ., 568, 391-401, https://doi.org/10.1016/j.scitotenv.2016.06.026, 2016.

Shiraiwa, M., Kondo, Y., Iwamoto, T., and Kita, K.: Amplification of Light Absorption of Black Carbon by Organic Coating, Aerosol Sci. Technol., 44, 46-54, https://doi.org/10.1080/02786820903357686, 2010.

Sumlin, B. J., Pandey, A., Walker, M. J., Pattison, R. S., Williams, B. J., and Chakrabarty, R. K.: Atmospheric Photooxidation Diminishes Light Absorption by Primary Brown Carbon Aerosol from Biomass Burning, Environ. Sci. Technol. Lett., 4, 540-545, https://doi.org/10.1021/acs.estlett.7b00393, 2017.

Sun, H., Biedermann, L., and Bond, T. C.: Color of brown carbon: A model for ultraviolet and visible light absorption by organic carbon aerosol, Geophys. Res. Lett., 34, 1-5, https://doi.org/10.1029/2007GL029797, 2007.

Teich, M., Van Pinxteren, D., Wang, M., Kecorius, S., Wang, Z., Müller, T., Močnik, G., and Herrmann, H.: Contributions of nitrated aromatic compounds to the light absorption of watersoluble and particulate brown carbon in different atmospheric environments in Germany and China, Atmos. Chem. Phys., 17, 1653-1672, https://doi.org/10.5194/acp-17-1653-2017, 2017.

Tian, J., Chow, J. C., Cao, J., Han, Y., Ni, H., Chen, L. A., Wang, X., Huang, R., Moosmüller, H., and Watson, J. G.: A Biomass Combustion Chamber?: Design, Evaluation, and a Case Study of Wheat Straw Combustion Emission Tests, Aerosol Air Qual. Res., 15, 2104-2114, https://doi.org/10.4209/aaqr.2015.03.0167, 2015.

Torres, O., Tanskanen, A., Veihelmann, B., Ahn, C., Braak, R., Bhartia, P. K., Veefkind, P., and Levelt, P.: Aerosols and surface UV products form Ozone Monitoring Instrument observations: An overview, J. Geophys. Res.-Atmos., 112, 1-14, https://doi.org/10.1029/2007JD008809, 2007.

Tsutsuki, K. and Kuwatsuka, S.: Chemical studies on soil humic acids, Soil Sci. Plant Nutr., 25, 501-512, https://doi.org/10.1080/00380768.1979.10433192, 1979.

Turetsky, M. R., Benscoter, B., Page, S., Rein, G., Van Der Werf, G. R., and Watts, A.: Global vulnerability of peatlands to fire and carbon loss, Nat. Geosci., 8, 11-14, https://doi.org/10.1038/ngeo2325, 2015. 
Van Krevelen, D. W.: Graphical-statistical method for the study of structure and reaction processes of coal, Fuel, 24, 269-284, 1950.

Varga, B., Kiss, G., Ganszky, I., Gelencsér, A., and Krivácsy, Z.: Isolation of water-soluble organic matter from atmospheric aerosol., Talanta, 55, 561-572, https://doi.org/10.1016/S00399140(01)00446-5, 2001.

Virkkula, A., Ahlquist, N. C., Covert, D. S., Arnott, W. P., Sheridan, P. J., Quinn, P. K., and Coffman, D. J.: Modification, calibration and a field test of an instrument for measuring light absorption by particles, Aerosol Sci. Technol., 39, 68-83, https://doi.org/10.1080/027868290901963, 2005.

Watts, A. C.: Organic soil combustion in cypress swamps: Moisture effects and landscape implications for carbon release, For. Ecol. Manage., 294, 178-187, https://doi.org/10.1016/j.foreco.2012.07.032, 2013.

Watts, A. C. and Kobziar, L. N.: Smoldering combustion and ground fires: ecological effects and multi-scale significance, Fire Ecology, 9, 124-132, https://doi.org/10.4996/fireecology.0901124, 2013.
Weber, R. J., Guo, H., Russell, A. G., and Nenes, A.: High aerosol acidity despite declining atmospheric sulfate concentrations over the past 15 years, Nat. Geosci., 9, 1-5, https://doi.org/10.1038/NGEO2665, 2016.

Xie, M., Hays, M. D., and Holder, A. L.: Light-absorbing organic carbon from prescribed and laboratory biomass burning and gasoline vehicle emissions, Sci. Rep., 7, 7318, https://doi.org/10.1038/s41598-017-06981-8, 2017.

Yu, Z. C.: Northern peatland carbon stocks and dynamics: A review, Biogeosciences, 9, 4071-4085, https://doi.org/10.5194/bg9-4071-2012, 2012.

Zhang, X., Lin, Y.-H., Surratt, J. D., and Weber, R. J.: Sources, Composition and Absorption Ångström Exponent of Lightabsorbing Organic Components in Aerosol Extracts from the Los Angeles Basin, Environ. Sci. Technol., 47, 3685-3693, https://doi.org/10.1021/es305047b, 2013.

Zhao, R., Lee, A. K. Y., Huang, L., Li, X., Yang, F., and Abbatt, J. P. D.: Photochemical processing of aqueous atmospheric brown carbon, Atmos. Chem. Phys., 15, 6087-6100, https://doi.org/10.5194/acp-15-6087-2015, 2015. 